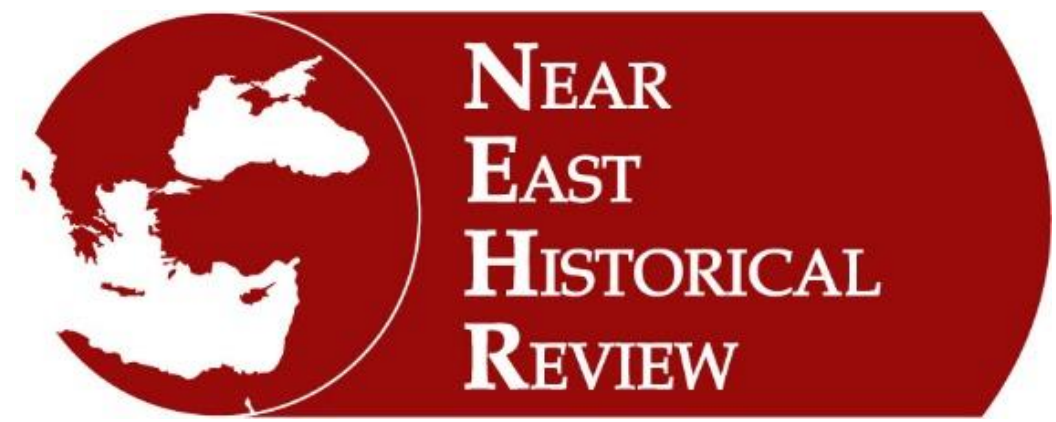

\title{
19. YÜZYIL ORTALARINDA AKDAĞ NAHIYESINDE SOSYAL HAYAT
}

Social Life in Akdağ District in mid-19th Century

\author{
Gülsara Korkut \\ Amasya Üniversitesi, Türkiye \\ e-mail: sare_rose_00@hotmail.com \\ ORCID ID: orcid.org/ 0000-0003-0727-0970
}

Near East Historical Review

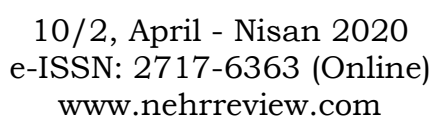

Article Type-Makale Türü : Research Article / Araştırma Makalesi

Received Date - Geliş Tarihi : 15.03 .2020

Accepted Date - Kabul Tarihi : 18.04 .2020

Pages-Sayfa : 173-203

doi : http://dx.doi.org/10.29228/nehrreview.42850

\footnotetext{
Citation-Attf : Gülsara Korkut, "93 Harbi'nde Şehit Olan Sivasli Askerler ve Sosyo-Ekonomik Durumlari", Near East Historical Review, 10/2, April 2020, pp. 173-203
} 



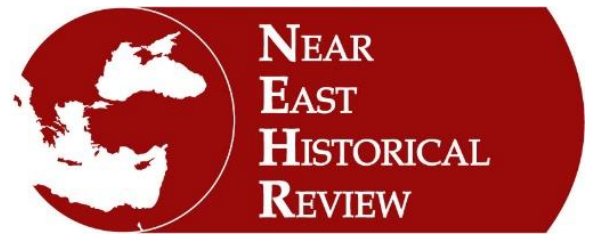

Near $\boldsymbol{E}$ ast $\boldsymbol{H}$ istorical Review

10/2, April - Nisan 2020

$173-203$

\section{YÜZYIL ORTALARINDA AKDAĞ NAHIYYESİNDE SOSYAL HAYAT*}

Social Life in Akdă District in mid-19 $9^{\text {th }}$ Century

Gülsara Korkut

Amasya Üniversitesi, Türkiye

\section{$\ddot{O} z$}

Osmanlı coğrafyasının merkeze yakın yerleşim yerleri baz alınarak tutulan Temettuat defterleri, ait oldukları döneme ilişkin sosyal ve iktisadi hayata 1şı tutan önemli belgelerdir. Kaza ve köylerin hane hane kayıtları tutulmuş, kişilere ait mal varlıkları tespit edilerek her hanenin gelirine göre vergi vermesi usulü ile adaletli bir vergi sistemi uygulanmaya çalışılmıştır. Tutulan kayıtlar, iktisadi bilgiler 1şı̆̆ında, sosyal ve kültürel birçok konuda da bilgi ve fikir sahibi olmaya katkı sağlamıştır. Akdağ Nahiyesinde vergiye tabi tutulan hane reislerinin isimleri, unvanları, lakapları, meslekleri ve nüfus özellikleri ile ilgili kayda değer bilgilere ulaşılmıştır. Bu çalışmada, 1844-1845 yılında tutulan Temettuat defterlerinde yer alan kayıtlardan hareketle 19.yüzyıl ortalarında Sivas Eyaleti, Amasya Sancağına bağlı Akdağ Nahiyesinde sosyal hayat incelenmiştir.

Anahtar Kelimeler: Osmanlı Devleti, Temettuat defteri, Akdağ nahiyesi, sosyal hayat

\begin{abstract}
Temettuat books, which are kept on the basis of settlements close to the center of the Ottoman geography, are important documents that shed light on social and economic life. Household records of accidents and villages were kept, and a fair tax system was tried to be applied by determining the assets of the individuals and paying taxes according to the income of each household. The records kept contributed to having knowledge and ideas in many social and cultural issues in the light of economic information. Significant information about the names, titles, nicknames, professions and population characteristics of household heads who were subject to tax in Akdag District was reached. In this study, based on the records in the Temettuat notebooks kept in 18441845 , social life was examined in Akdağ District in the mid-19th century.
\end{abstract}

Keywords: Ottoman State, Temettuat Registers, Akdağ, Social life

\footnotetext{
* Bu çalışma yazarın “19. Yüzyılın Ortalarında Akdağ Nahiyesi’nin Sosyal ve Ekonomik Yapısı” başlıklı Yüksek Lisans tezinden üretilmiştir.
}

Near East Historical Review 


\section{Giriş}

Tarla kültürü ve hayvancılık ilk çağlardan itibaren Anadolu ekonomisinin temeli olmuş, Roma, Bizans, Osmanlı gibi Akdeniz iklim kuşağındaki devletlerde tarım ve hayvancığa dayanan bir ekonomi modeli olarak devam etmiştir. Bu yapı köy yerleşimi ve köylü emeği üzerinden gelişmiştir. Köy köylünün yaşadığı yerleşim yeri, köylü ise tarım ve hayvancılıkla uğraşan, bağ bahçe yetiştiren, kendi mülkü olmayan topraklarda yaşayan, yaşayışları birbirine benzeyen kimselerdir. ${ }^{1} \mathrm{Bu}$ mekanizmayı ayakta tutan ise, köylülerin geçimlerini ve iktisadi faaliyetlerini kanunlar tarafindan destekleyen, "ahlaki ekonomi yönetimi" idi. Bu şekilde köylünün de isteklerine cevap verilmiş oluyor, devlet ile üretici arasında bütünlük sağlanıyordu. ${ }^{2}$

16. yüzyılın sonlarına gelindiğinde Osmanlı Devleti, hem içte hem dışta yaşanan olumsuzlukların etkisiyle sosyal ve ekonomik birçok açıdan düzeninin bozulduğu bir çözülme dönemine girmiştir. Kurumların eski işlevini yitirmesi, tımar sisteminin bozulması bazı girişimler ile kurtarılmaya çalışılan ekonominin daha da kötü hale gelmesi ile ekonomik ve toplumsal düzen sarsılmıştır. ${ }^{3} 16$. yüzyılın sonunda başlayan bu mali bunalım daha sonraki yüzyıllarda da devam etmiş, devletin içinde bulunduğu krizin aşılması için bazı girişimlerde bulunulmuştur. ${ }^{4}$ Tanzimat ile yeni birçok uygulama konulmuş, vergi sisteminde ise şer'i vergiler yerine zirai ürünlerden onda bir, küçükbaş hayvanlardan ağnam ve gayrimüslimlerden cizye alınması, birden çok isim altında alınan vergi türleri yerine bütün olarak alınan "Ancematin vergi", "Vergü-yi Mahsusa" gibi isimlerle adlandırılan yeni vergi uygulanmaya başland1. ${ }^{5}$ Temettuat vergisi, Tanzimattan önce farklı isimlerle alınan bu vergilerin yerine getirilmiştir. Tüccar, esnaf, köylü, şehirli hane reislerinin y1llık kazançları tespit edilerek tahrir olunan bu vergiler, temettuat defterlerine kaydedilmiştir. ${ }^{6}$ Çalıştığı bölge ile ilgili sosyo-ekonomik ve sosyo-kültürel bilgiler ortaya koymak isteyen tarihçilerin bu çalışmalar içerisinde birincil kaynaklar olarak incelemeleri gereken en önemli kaynaklardan biri kuşkusuz bu defterlerdir.

$\mathrm{Bu}$ çalışmanın amacı 1845 yılına ait temettuat defterlerinden hareketle, 19. yüzyıl Sivas Eyaleti, Amasya Sancağına bağlı Akdağ Nahiyesinin sosyal yapısı ve bu yapıya dahil olan nüfus, hane reislerinin isimleri, hane reislerinin kullandıkları lakaplar, unvanlar ve icra edilen meslekler belirlenerek, bu bilgiler 1şığında dönemin sosyal ve kültürel yapısının ortaya konulmasidir.

\section{19. Yüzyılın Ortalarında Akdağ Nahiyesinde Sosyal Hayat}

Akdağ Nahiyesi Amasya'nın merkezi yerleşimlerinden birisidir. Amasya Sancağına ait tahrirlerde Amasya; Merzifon, Havza, Gümüşhacıköy, Zeytun ve Ladik Kazalarına ayrılmıştır. Temettuat kayıtlarında ise Amasya, Akdağ, Geldiklan, Ezinepazar ve Hakala nahiyelerini de kapsamaktadır. ${ }^{7}$ Akdağ Nahiyesi Amasya'nın doğusunda kalmaktadır. Merkezi Akviran Köyü'dür. Doğudan batıya doğru uzanan, Akdağ ismiyle anılan bir dağın eteklerinde kurulmuş olmasından dolayı bu adı almıştır. Yaylasının bol, kışlağının güzel, havasının sağlam olmasından dolayı koyunlar çoğunlukla yazın burada otlatılır. Yağı, peyniri, yoğurdunun şöhretli olduğu

\footnotetext{
${ }^{1}$ İsmail Arslan, Osmanl Dünyasında Köyler ve Köylüler, Bilge Kültür Sanat, İstanbul 2014, s. 75.

${ }^{2}$ Hurcihan İslamoğlu, Osmanlı Imparatorluğu'nda Devlet ve Köylü, İletişim Yayınları, İstanbul 1991, s. 94.

${ }^{3}$ Said Öztürk, Tanzimat Döneminde Bir Anadolu Şehri Bilecik, Kitapevi, İstanbul, s. 19.

${ }^{4}$ Coşkun Çakır, Tanzimat Dönemi Osmanlı Maliyesi, Küre Yayınları, İstanbul 2001, s. 18.

${ }^{5}$ S. Öztürk,a.g.e., s.174.

${ }^{6}$ İsmail Arslan, "XIX.Yüzyıl Osmanlı Tarihinde Temettuat Defterlerinin Yeri:İ̆giç Selimağa Köyü Temettuat Defteri Örneği”, Balıkesir Üniversitesi Sosyal Bilimler Enstitüsü Dergisi, Balıkesir 2002, s.58.

${ }^{7}$ Songül Keçeci Kurt, "1844-1845 Temettuat Defterlerine Göre Ziyere Köyü’nün Sosyal ve Ekonomik Durumu’, History Studies, 2016, s.58.
} 
bilinmektedir. Akdağ Nahiyesi içerisinde birçok âlim yetişmiş, burada vakıf, zaviye, tekke ve türbeler inşaetmişlerdir. ${ }^{8}$

\subsection{Akdağ Nahiyesinde İkamet Eden Erkek Hane Reislerinin İsimleri}

Kişileri birbirinden ayıran en önemli özelliklerinden biri taşıdığı ismidir. Temettuat sayımlarında kişilerin isimleri baba adıyla, lakabıyla ya da ait olduğu sülale ismi ile birlikte verilmiştir. ${ }^{9} \mathrm{Kişiler,} \mathrm{isim} \mathrm{ve} \mathrm{lakabının} \mathrm{yanında} \mathrm{mesleği,} \mathrm{şu} \mathrm{veya} \mathrm{bu} \mathrm{kişinin} \mathrm{zevcesi,} \mathrm{kerimesi}$ şeklinde yazılmıştır. ${ }^{10} \mathrm{Bu}$ sayımlar hane esas alınarak yapılmış, vergiye tabi olan hane reisinin adı defterlerin başına kaydolunmuştur. ${ }^{11} \mathrm{Bu}$ isimler çoğunlukla "oğlu" ibaresi kullanılarak yazılmıştır.

Akdağ Nahiyesinde 861 hane reisi tarafindan kullanılan 76 farklı isim tespit edilmiştir. $\mathrm{Bu}$ isimler arasında 13 hane reisinin isimleri, Kareki, Dimitri, Nikola, Yahi, Nikofas, Yuvan, Lanbi, Yako, Vasil, Savan, Petro, Yalofa, Senan olarak kaydedilmiştir. Bu kişilerin gayrimüslim olduğu kuvvetle muhtemeldir.

$\mathrm{Bu}$ kişiler dışında gayrimüslim isimlerine rastlanmayışı köy nüfusunun büyük çoğunluğunun Müslüman olduğunu göstermektedir. Müslüman hane reisleri çoğunlukla İslamiyet'in önde gelen şahıslarına, Ehlibeyte ve dört büyük halifeye ait isimleri kullanmaktadırlar.

Akdağ Nahiyesine kayıtlı hane reislerine ait isimler içerisinde en fazla kullanılan 130 defa ile Mehmet ismidir. Mehmet, Mustafa ve Ahmet isimleri peygambere atfen kullanılan isimler olup özellikle Muhammed ismine kutsallık yüklenerek daha çok saygı gösterildiğinden Muhammed ismini doğrudan kullanmak yerine, daha çok Mehmet ismi tercih edilmiştir. ${ }^{12}$ Mehmet isminden sonra en çok kullanılan isimlerin sırasıyla, 89 kez Ali ve 74 kez Mustafa olduğu görülmektedir. Hüseyin, Ahmet, Hasan, Osman, Ömer ve İbrahim isimleri de en çok kullanılan isimlerdendir. Kullanılan isimlerden yola çıkarak Akdağ Nahiyesinde dini değerlere önem verildiğini, islami değerlerin etkisinin isimler üzerinden yaşatıldığını görmekteyiz.

Akdağ Nahiyesinde hane reislerine ait en çok kullanılan isimler, sıklıkları ve yüzdelikleri tablo 1'de ayrıntılı bir şekilde gösterilmiştir.

Tablo 1. Erkek Hane Reislerinin İsimleri ve Kullanım Sıklıkları

\begin{tabular}{llll}
\hline Sıra No & Kullanılan İsim & Kullanım Sıklı̆̆ı & Yüzdelik Oran \\
\hline $\mathbf{1}$ & Mehmed & 130 & $\% 15.0$ \\
$\mathbf{2}$ & Ali & 89 & $\% 10.3$ \\
$\mathbf{3}$ & Mustafa & 74 & $\% 8.6$ \\
$\mathbf{4}$ & Hüseyin & 70 & $\% 8.2$ \\
$\mathbf{5}$ & Ahmed & 69 & $\% 7.10$ \\
$\mathbf{6}$ & Hasan & 53 & $\% 6.2$ \\
\hline
\end{tabular}

${ }^{8}$ Hüseyin Hüsameddin Yaşar, Amasya Tarihi, Hazırlayan M.Aydın ve G.Aydın, Amasya Belediyesi, Amasya 2007, s. 231.

9 Ilker Mümin Çağlar, “Temettuat Kayıtlarına Göre İzzeddin Köyü’nün Sosyo Ekonomik Durumu (1844-1845)”, Sosyal Bilimler Dergisi, 2015, s.420.

${ }^{10}$ Zeynel Özlü, Tanzimat Dönemi'nde Anadolu'da Kır ve Kent hayatı (Bolu-Göynük Örneği), Berikan Yayınları, Ankara 2007, s.9.

${ }^{11}$ Nuri Adıyeke, “Temettuat Sayımları ve Bu Sayımları Düzenleyen Nizamname Örnekleri”, OTAM. , Sayı:11, 2000, s.774.

12 İbrahim Serbestoğlu, 19.Yüzyılda Amasya Sancă̆ , Amasya 2018, s.28. 


\begin{tabular}{|c|c|c|c|}
\hline 7 & Osman & 53 & $\% 6.2$ \\
\hline 8 & Ömer & 49 & $\% 5.7$ \\
\hline 9 & İbrahim & 41 & $\% 4.8$ \\
\hline 10 & Abdullah & 27 & $\% 3.2$ \\
\hline 11 & Halil & 22 & $\% 2.6$ \\
\hline 12 & İsmail & 21 & $\% 2.5$ \\
\hline 13 & Süleyman & 15 & $\% 1.8$ \\
\hline 14 & Bekir & 11 & $\% 1.3$ \\
\hline 15 & Seyyid & 10 & $\% 1.2$ \\
\hline 16 & Abdurrahman & 8 & $\% 0.9$ \\
\hline 17 & Emrullah & 7 & $\% 0.8$ \\
\hline 18 & Emin & 7 & $\% 0.8$ \\
\hline 19 & Kadir & 6 & $\% 0.6$ \\
\hline 20 & Abdülkadir & 5 & $\% 0.5$ \\
\hline 21 & Abdi & 5 & $\% 0.5$ \\
\hline 22 & Hafiz & 5 & $\% 0.5$ \\
\hline 23 & Yusuf & 5 & $\% 0.5$ \\
\hline 24 & Veli & 4 & $\% 0.4$ \\
\hline 25 & Musa & 4 & $\% 0.4$ \\
\hline 26 & Salih & 4 & $\% 0.4$ \\
\hline 27 & Sadullah & 3 & $\% 0.3$ \\
\hline 28 & Kasım & 3 & $\% 0.3$ \\
\hline 29 & Mikail & 3 & $\% 0.3$ \\
\hline 30 & Abdüllatif & 2 & $\% 0.2$ \\
\hline 31 & İsa & 2 & $\% 0.2$ \\
\hline 32 & Recep & 2 & $\% 0.2$ \\
\hline 33 & Şerif & 2 & $\% 0.2$ \\
\hline 34 & Himmet & 2 & $\% 0.2$ \\
\hline 35 & Hızır & 2 & $\% 0.2$ \\
\hline 36 & Mahmud & 2 & $\% 0.2$ \\
\hline 37 & Abidin & 2 & $\% 0.2$ \\
\hline 38 & Kareki & 2 & $\% 0.2$ \\
\hline 39 & Dimitri & 2 & $\% 0.2$ \\
\hline
\end{tabular}

Near East Historical Review 


\begin{tabular}{|c|c|c|c|}
\hline 40 & Nikola & 2 & $\% 0.2$ \\
\hline 41 & Halid & 1 & $\% 0.1$ \\
\hline 42 & Mesud & 1 & $\% 0.1$ \\
\hline 43 & Abdülgani & 1 & $\% 0.1$ \\
\hline 44 & Hasan Ali & 1 & $\% 0.1$ \\
\hline 45 & Yahi & 1 & $\% 0.1$ \\
\hline 46 & Yakup & 1 & $\% 0.1$ \\
\hline 47 & Cuma & 1 & $\% 0.1$ \\
\hline 48 & Aziz & 1 & $\% 0.1$ \\
\hline 49 & Alemdar & 1 & $\% 0.1$ \\
\hline 50 & Muhammed & 1 & $\% 0.1$ \\
\hline 51 & Said & 1 & $\% 0.1$ \\
\hline 52 & Hacı Fakı & 1 & $\% 0.1$ \\
\hline 53 & Davud & 1 & $\% 0.1$ \\
\hline 54 & Satılmış & 1 & $\% 0.1$ \\
\hline 55 & Nazif & 1 & $\% 0.1$ \\
\hline 56 & Sabri & 1 & $\% 0.1$ \\
\hline 57 & Eyüb & 1 & $\% 0.1$ \\
\hline 58 & Muhterem & 1 & $\% 0.1$ \\
\hline 59 & Feyzullah & 1 & $\% 0.1$ \\
\hline 60 & Abdulhalim & 1 & $\% 0.1$ \\
\hline 61 & Abdurrahim & 1 & $\% 0.1$ \\
\hline 62 & Selim & 1 & $\% 0.1$ \\
\hline 63 & Zaim & 1 & $\% 0.1$ \\
\hline 64 & Seyyid Ahmed & 1 & $\% 0.1$ \\
\hline 65 & Hüseyin Şaban & 1 & $\% 0.1$ \\
\hline 66 & Mehmed Ali & 1 & $\% 0.1$ \\
\hline 67 & Nikofas & 1 & $\% 0.1$ \\
\hline 68 & Yuvan & 1 & $\% 0.1$ \\
\hline 69 & Lanbi & 1 & $\% 0.1$ \\
\hline 70 & Yako & 1 & $\% 0.1$ \\
\hline 71 & Vasil & 1 & $\% 0.1$ \\
\hline 72 & Savan & 1 & $\% 0.1$ \\
\hline
\end{tabular}




\begin{tabular}{llll}
\hline $\mathbf{7 3}$ & Petro & 1 & $\% 0.1$ \\
$\mathbf{7 4}$ & Yalofa & 1 & $\% 0.1$ \\
$\mathbf{7 5}$ & Senan & 1 & $\% 0.1$ \\
Toplam & & 860 & $\% 100$ \\
\hline
\end{tabular}

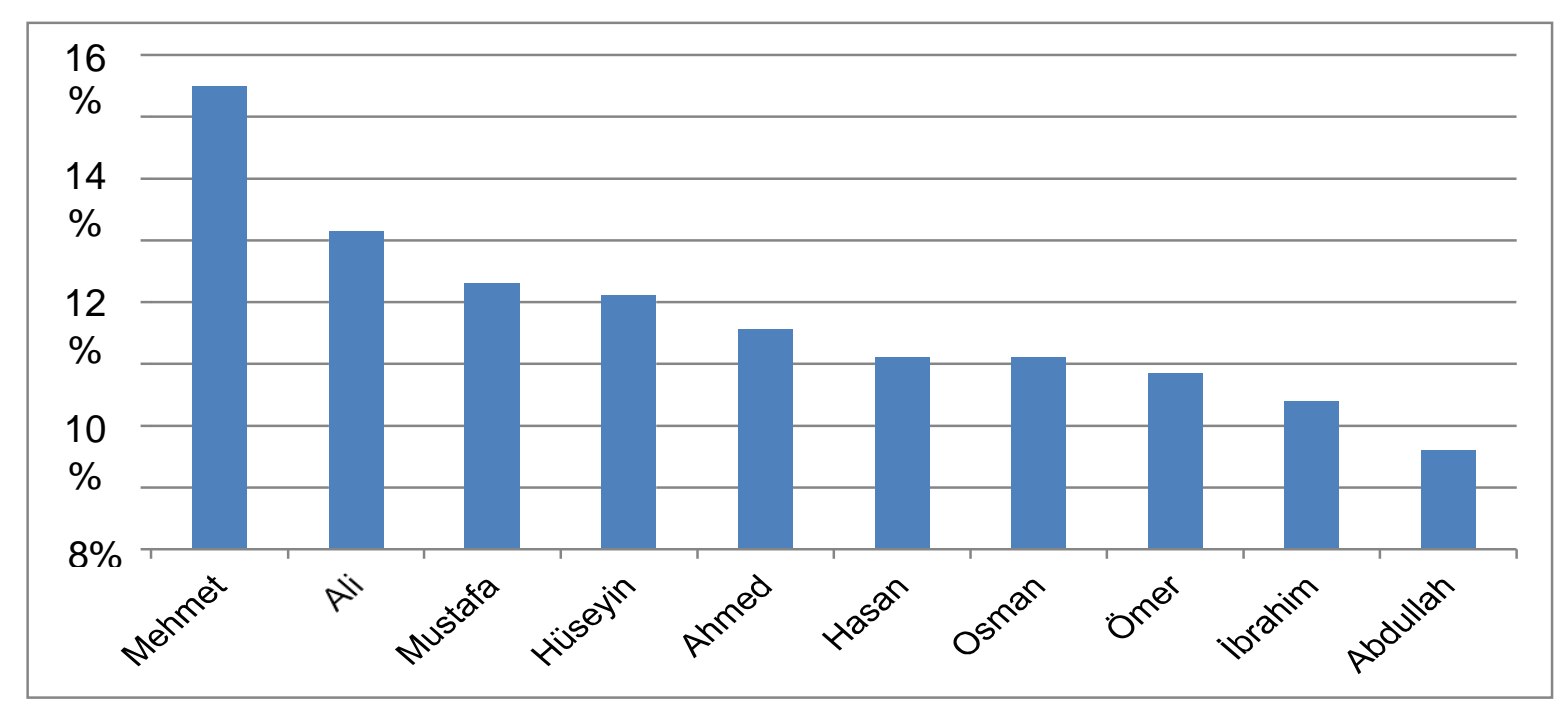

Şekil 1. Erkek hane reislerinin sık kullandıkları isimler

\subsection{Kadın Hane Reislerinin Adlart}

Akdağ Nahiyesine ait temettuat kayıtlarında 861 erkek hane reisi dışında, 14 Müslüman ve 4 gayrimüslim olmak üzere toplam 18 kadın hane reisi ismine rastlanmaktadır. Müslüman kadın hane reislerine ait isimler Fatma,Emine,Zeynep, Şerife, Hafize, Azime, Ayşe'dir. İsimlere bakıldığında çoğunun peygamberimizin kızı ve eşinin adına ithaf olunduğu, İslami değerlerin erkek isimlerinin yanında kadın isimleri üzerinde de yaşatıldığı görülmektedir. Kayıtlarda Müslüman kadın isimlerinin dışında Sofia, Meryem, Maria ve Vesine adı ile yazılmış dört tane gayrimüslim kadın ismine rastlanmıştır. Tespit edilen 12 kadın hane reisinden 8 tanesi, 152 hane ile nahiyenin en kalabalık köyü olan Ziğere'de ikamet etmektedir. Gayrimüslim kadınların da hepsi Ziğere Yukarı Mahallede, sırasıyla 144, 145, 146 ve 147 nolu hanelerde ikamet etmektedir. Kadın hane reislerinin isimleri, erkek hane reisleriyle olan akrabalık belirtilerek, kerimesi, zevcesi, kızı ve karısı şeklinde yazılmıştır. Tablo 2'de kadın hane reislerinin isimleri ve kullanım s1klıkları görülmektedir. 
ablo 2. Kadın Hane Reislerinin İsimleri ve Kullanım Sıklıkları

\begin{tabular}{llll}
\hline Sıra No & Kullanılan İsim & Kullanım Sıklı̆̆ı & Yüzdelik Oran \\
\hline $\mathbf{1}$ & Fatma & 4 & $\% 22.2$ \\
$\mathbf{2}$ & Emine & 3 & $\% 16.6$ \\
$\mathbf{3}$ & Zeynep & 2 & $\% 11.1$ \\
$\mathbf{4}$ & Şerife & 1 & $\% 5.5$ \\
$\mathbf{5}$ & Hafize & 1 & $\% 5.5$ \\
$\mathbf{6}$ & Azime & 1 & $\% 5.5$ \\
$\mathbf{7}$ & Sofia & 1 & $\% 5.5$ \\
$\mathbf{8}$ & Meryem & 1 & $\% 5.5$ \\
$\mathbf{9}$ & Maria & 1 & $\% 5.5$ \\
$\mathbf{1 0}$ & Vesine & 1 & $\% 5.5$ \\
$\mathbf{1 1}$ & Ayşe & 1 & $\% 5.5$ \\
$\mathbf{1 2}$ & Hacı karı & 1 & $\% 5.5$ \\
Toplam & & 18 & \\
\hline
\end{tabular}

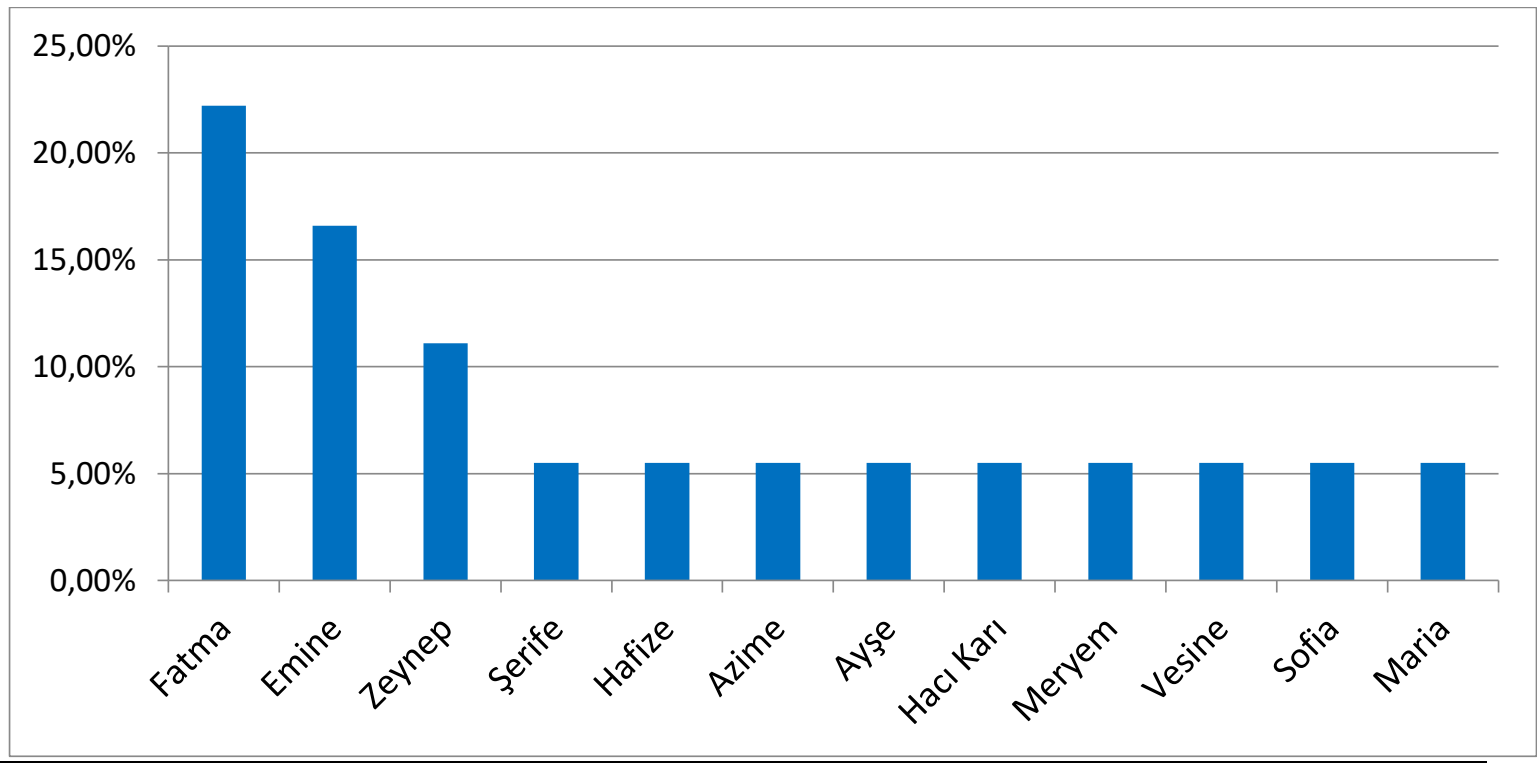

Şekil 2. Kadın hane reislerinin sık kullandıkları isimler

Near East Historical Review

www.nehrreview.com 


\subsection{Unvanlar}

Temettuat kayıtlarının yazıldığı dönemde soyadı olmadığı için, vergi mükellefleri defterlere uğraştıkları meslek, ait oldukları aile isimleri veya kendilerine ait bazı ayırt edici fiziksel özellikleri ile kaydedilmişlerdir. Unvan, bunlar içerisinde önemli yeri tutmuştur. ${ }^{13}$

Türkçe'de kişinin sahip olduğu memuriyet vazifesini ve derecesini belirten terim olarak unvan kelimesi "kitap, mektup ve yazı başlı̆̆ı" anlamına gelmektedir. Unvan kullanımı çok eskiye dayanan bir gelenektir. Türk, Arap ve İran devletlerinde çokça kullanılmışlardır. Birçok Türk hükümdarı çeşitli unvanlar kullanmışlardır. Han, hakan, ilig, idikut, tamgaç gibi unvanlar hükümdarların; hatun ve katun gibi unvanlar da hükümdar eşlerinin çokça kullandığı unvanlar olmuştur. Osmanlı Devleti'nde ise bey, han gibi unvanlar Türk geleneğinin, sultan, halife ve hüdavendigar gibi unvanlar İslami geleneğin devamı olarak çokça kullanılmıştır. ${ }^{14}$

17. yüzyıla gelindiğinde unvan kullanımı, Osmanlıda klasik dönemdeki amacının dışında, kişilerin güç kazandığı sosyo-politik bir amaca dönüşmüştür.Soyu belli olmayan kişilerce, zanaatkar ve mahkumlara kadar bir statü kazanma, itibar edinme, tanınma ve korunma aracı olarak suiistimal edilebilmiştir. ${ }^{15}$

Akdağ Nahiyesinde hane reislerinin kullandıkları 8 farklı unvan tespit edilmiştir. Bu unvanlar; hac1, efendi, molla, ağa, hatun, kâhya, derviş ve beydir. Bu unvanlar 66 hane reisi tarafından kullanılmıştır. En fazla kullanılan unvan "hacı"dır. Hacı unvanını kullananların dini sorumluluklarını yerine getirdikleri ve bu vazifeyi yerine getirecek maddi güçlerinin olduğu tahmin edilmektedir. ${ }^{16}$ Hacı sıfatından sonra en çok kullanılan unvan efendi olmuştur. 17 hane reisi tarafından kullanılmıştır. Anadolu' daki kullanımı "sahip ve malik" anlamlarına gelen efendi unvanı, 17.yüzyıldan sonra yüksek dereceli memurlara verilen eğitimli ve saygıdeğer anlamında kullanılan bir unvan olmuştur. ${ }^{17}$ Efendi unvanından sonra en çok molla kullanılmıştır. Bu unvan, bazı İslam toplumlarında tanınmış din âlimlerine verilen unvandır. ${ }^{18}$ Kullanılan lakaplar kişilerin dini statüleri hakkında bilgi vermektedir.

\footnotetext{
13 Sevcan Aslan, Temettuât Defterlerine Göre XIX. yy. Ortalarında Gümüşhacıköy Kazası'nın Sosyo-Ekonomik Durumu (1844-1845), Yayımlanmamış Yüksek Lisans Tezi, Eskişehir Osmangazi Üniversitesi Sosyal Bilimler Enstitüsü, Eskişehir 2015, s.18.

${ }^{14}$ Abdülkerim Özaydın-Mehmet İpşirli, “Unvan”, Türkiye Diyanet Vakfi İslam Ansiklopedisi, Cilt:30, Türkiye Diyanet Vakfi Yayınları, İstanbul 2012, s.163.

15 Turan Açık, "Bey”likten “Ağa”lığa: 17. Yüzyılın İlk Yarısında Trabzon'da "Unvan Enflasyonu”, Karadeniz Incelemeleri Dergisi, 2014, s.12-37.

${ }^{16}$ Mübahat Kütükoğlu, “Osmanlı Sosyal ve İktisadi Tarihi Kaynaklarından Temettü Defterleri”, Belleten, Say1:225, 1995, s.402.

${ }^{17}$ Orhan Fuad Köprülü, "Efendi”, Türkiye Diyanet Vakfi İslam Ansiklopedisi, Cilt:10, Türkiye Diyanet Vakfi Yayınları, İstanbul 2012, s.456.

${ }^{18}$ Hamid Algar,“Molla”, Türkiye Diyanet Vakfi İslam Ansiklopedisi, Cilt:10, Türkiye Diyanet Vakfi Yayınları, İstanbul 2005, s.238.
}

Near East Historical Review 
Tablo 3. Hane Reislerinin Kullandıkları Unvanlar ve Kullanım Sıklıkları

\begin{tabular}{llll}
\hline Sıra No & Kullanılan Unvan & Kullanım Sıklı̆̆ı & Kullanım Yüzdesi \\
\hline $\mathbf{1}$ & Hacı & 21 & $\% 30.8$ \\
$\mathbf{2}$ & Efendi & 17 & $\% 25$ \\
$\mathbf{3}$ & Molla & 10 & $\% 14.7$ \\
$\mathbf{4}$ & Ağa & 8 & $\% 11.7$ \\
$\mathbf{5}$ & Hatun & 7 & $\% 10.2$ \\
$\mathbf{6}$ & Kahya & 1 & $\% 1.4$ \\
$\mathbf{7}$ & Derviş & 1 & $\% 1.4$ \\
$\mathbf{8}$ & Bey & 1 & \\
Toplam & & 66 & \\
\hline
\end{tabular}

Kullanılan unvanlar içerisinde zenginlik ifade eden ve günümüzde halen anlamını kaybetmemiş olan ağa unvanı 8 hane reisi tarafindan kullanılmıştır. ${ }^{19} \mathrm{Kad} ı n$ hane reislerinden 8 tanesi hatun unvanını kullanmıştır. Buradan eski Türk geleneklerine bağlılığın devam ettiğini görebiliyoruz. En az kullanılan unvanlar ise erkek hane reislerinden 1'er kişinin kullandığı kâhya, bey ve derviş unvanı olmuştur.

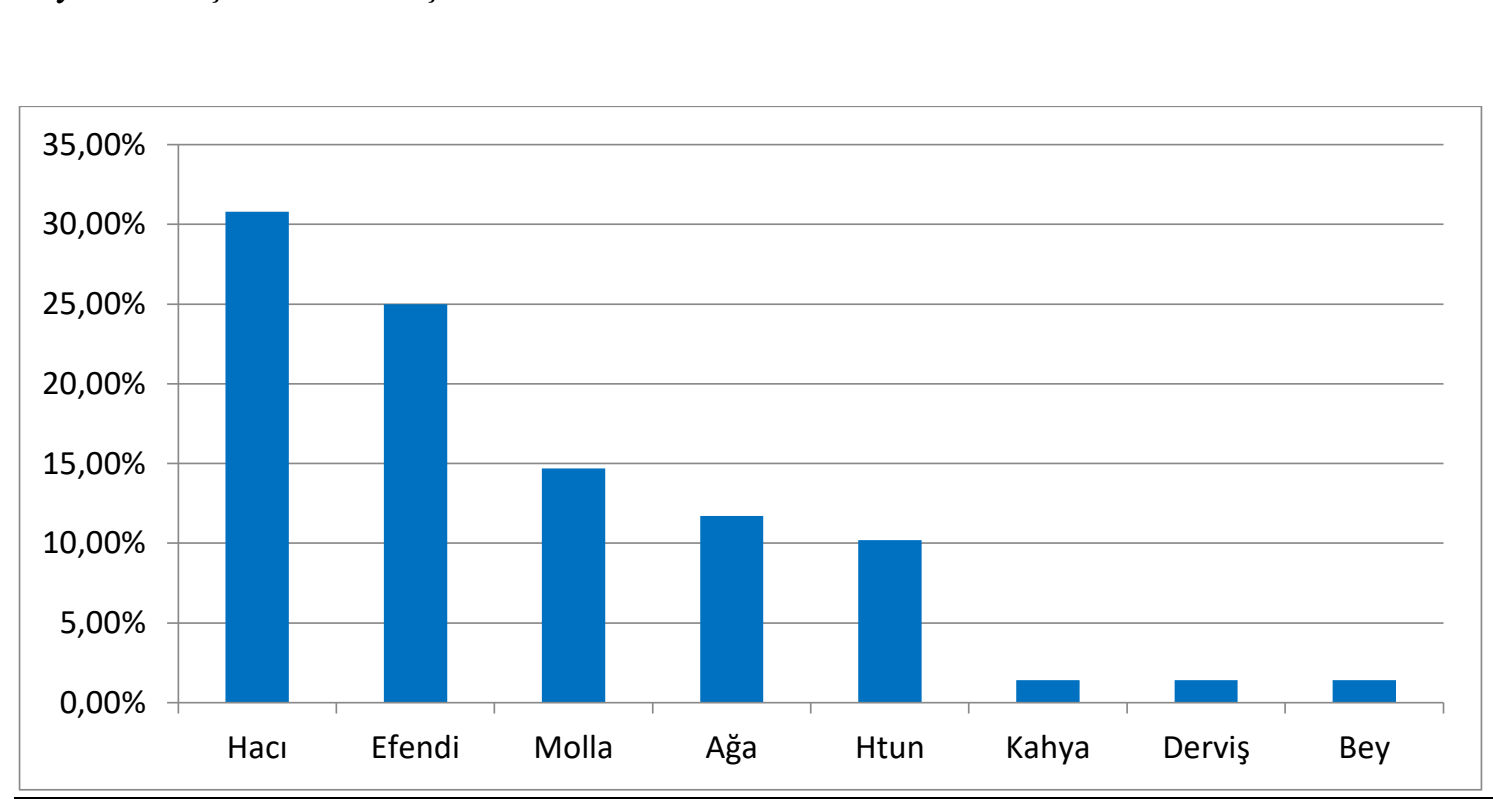

Şekil 3.Sıklıkla kullanılan unvanlar

${ }^{19}$ S. Aslan, a.g.t., s. 19

Near East Historical Review 


\subsection{Lakaplar}

Lakap, kişinin bilinmesinden hoşlanmadığı bir kusuruyla ona hitap etmek anlamına gelmektedir. Daha sonraları kişinin sevdiği ve onu toplumda yücelten anlamında kullanılarak, kişilerin olumlu ve olumsuz yönlerine işaret eden bir terim olmuştur. ${ }^{20}$ Unvanlardan farklı olarak, lakaplar daha çok kişinin değiştiremeyeceği özelliklerine göre verilmiştir. ${ }^{21}$ Lakaplar fiziksel görünüm, vücutta göze çarpan bir özellik yada karakter özelliğine göre takılmıştır. ${ }^{22}$ Lakap takmak Türklerde eski bir gelenek olup, Anadoludaki çoğu aile ve sülaleler mutlaka bir lakap kullanmışlardır. Kişilerin akrabalıkları bu lakaplarla anlaşılabilmektedir. ${ }^{23}$

\subsection{1. Özellik Bildiren Lakaplar}

Lakapların kişilerin daha çok değiştiremeyeceği özelliklerine göre verildiğini daha önce söylemiştik. Hane reislerinin kullandıkları lakaplar kişilere rastgele değil, sosyal, fiziksel ve sağlık durumlarına göre verilmiştir. Tablo 4'te özellik bildiren lakaplar ve kullanım yüzdeleri gösterilmiştir. Hane reislerinin kullandığ 67 farklı lakap tespit edilmiş ve bu lakaplar 171 hane reisi tarafından kullanılmıştır. Lakaplar içerisinde en çok kara, sarı, keleş, deli, uzun, öksüz, topal, cücük, kör, saçıkbaş, sağır, köse, dilsiz, ayyaş ve açıkgöz lakaplarının kullanıldığı görülmektedir. En fazla kullanılan kara ve sarı lakaplarının kişiye ten ve saç renginden dolayı verildiği düşünülmektedir. Kullanılan lakapların geneli kişinin belirgin fiziki yönlerine göre, eksik ya da işlevini yitirmiş olan olan bir uzvuna dikkat çekilerek verilmiştir.

Tablo 4. Özellik Bildiren Lakaplar

\begin{tabular}{llll}
\hline Sıra No & Kullanılan Lakap & Kullanım Sıklı̆̆ & Kullanım Yüzdesi \\
\hline $\mathbf{1}$ & Kara & 37 & $\% 24$ \\
$\mathbf{2}$ & Sarı & 22 & $\% 14.4$ \\
$\mathbf{3}$ & Keleş & 11 & $\% 7.2$ \\
$\mathbf{4}$ & Deli & 9 & $\% 5.9$ \\
$\mathbf{5}$ & Uzun & 7 & $\% 4.6$ \\
$\mathbf{6}$ & Öksüz & 6 & $\% 3.9$ \\
$\mathbf{7}$ & Topal & 6 & $\% 3.9$ \\
$\mathbf{8}$ & Cücük & 4 & $\% 2.6$ \\
$\mathbf{9}$ & Kör & 4 & $\% 2.6$ \\
\hline $\mathbf{1 0}$ & Saçıkbaş & 3 & $\% 1.9$ \\
\hline $\mathbf{1 1}$ & Dilsiz & 2 & $\% 1.3$ \\
\hline $\mathbf{1 2}$ & Köse & 2 & $\% 1.3$ \\
\hline
\end{tabular}

\footnotetext{
${ }^{20}$ Nebi Bozkurt-Mehmet İpşirli, "Lakap”, Türkiye Diyanet Vakfi İslam Ansiklopedisi, Cilt: 27, Türkiye Diyanet Vakfi Yayınları, Ankara 2003, s.65-67.

${ }^{21}$ S. Aslan, a.g.t., s.20.

22 Necati Çavdar, "1844-1845 yıllarında Taşabad Kazası Köylerinin İçtimai ve İktisadi Şartlarına Dair Tespitler" III. Uluslararası Geçmişten Günümüze Merzifon ve Amasya Yöresi Sempozyumu Bildiri Kitabı, 2015, s.213.

${ }^{23}$ N. Bozkurt- M. İpşirli, a,g.m., s.65-67.
} 


\begin{tabular}{|c|c|c|c|}
\hline 13 & Sağır & 2 & $\% 1.3$ \\
\hline 14 & Ayyaş & 2 & $\% 1.3$ \\
\hline 15 & Açıkgöz & 2 & $\% 1.3$ \\
\hline 16 & Küçük & 1 & $\% 0.6$ \\
\hline 17 & Boz & 1 & $\% 0.6$ \\
\hline 18 & Maviş & 1 & $\% 0.6$ \\
\hline 19 & Bodur & 1 & $\% 0.6$ \\
\hline 20 & Çıyan & 1 & $\% 0.6$ \\
\hline 21 & Kuru & 1 & $\% 0.6$ \\
\hline 22 & Dişiuzun & 1 & $\% 0.6$ \\
\hline 23 & Çirkin & 1 & $\% 0.6$ \\
\hline 24 & Solak & 1 & $\% 0.6$ \\
\hline 25 & Kancık & 1 & $\% 0.6$ \\
\hline 26 & Yavaş & 1 & $\% 0.6$ \\
\hline 27 & Usul & 1 & $\% 0.6$ \\
\hline 28 & Karga & 1 & $\% 0.6$ \\
\hline 29 & Cücükgöz & 1 & $\% 0.6$ \\
\hline 30 & Aygir & 1 & $\% 0.6$ \\
\hline 31 & Şişik & 1 & $\% 0.6$ \\
\hline 32 & Kaba & 1 & $\% 0.6$ \\
\hline 33 & Cin & 1 & $\% 0.6$ \\
\hline 34 & Biyık & 1 & $\% 0.6$ \\
\hline 35 & Karabıyık & 1 & $\% 0.6$ \\
\hline 36 & Kızkapan & 1 & $\% 0.6$ \\
\hline 37 & Karayılan & 1 & $\% 0.6$ \\
\hline 38 & Karabacak & 1 & $\% 0.6$ \\
\hline 39 & Karagöz & 1 & $\% 0.6$ \\
\hline 40 & Kıyye bal & 1 & $\% 0.6$ \\
\hline 41 & Dobez & 1 & $\% 0.6$ \\
\hline 42 & Koneş & 1 & $\% 0.6$ \\
\hline 43 & Çorukçu & 1 & $\% 0.6$ \\
\hline 44 & Çolak & 1 & $\% 0.6$ \\
\hline 45 & Tülek & 1 & $\% 0.6$ \\
\hline
\end{tabular}




\begin{tabular}{|c|c|c|c|}
\hline 46 & Kart & 1 & $\% 0.6$ \\
\hline 47 & Tenten & 1 & $\% 0.6$ \\
\hline 48 & Muhavven & 1 & $\% 0.6$ \\
\hline 49 & Yak1 & 1 & $\% 0.6$ \\
\hline 50 & Dipi & 1 & $\% 0.6$ \\
\hline 51 & Hartlık & 1 & $\% 0.6$ \\
\hline 52 & Ziskir & 1 & $\% 0.6$ \\
\hline 53 & Mancı & 1 & $\% 0.6$ \\
\hline 54 & Hezre & 1 & $\% 0.6$ \\
\hline 55 & Penyal & 1 & $\% 0.6$ \\
\hline 56 & Kavık & 1 & $\% 0.6$ \\
\hline 57 & Toğnuk & 1 & $\% 0.6$ \\
\hline 58 & Tekyenişin & 1 & $\% 0.6$ \\
\hline 59 & Kıkne & 1 & $\% 0.6$ \\
\hline 60 & Uzeyik & 1 & $\% 0.6$ \\
\hline 61 & Mancük & 1 & $\% 0.6$ \\
\hline 62 & Mazit & 1 & $\% 0.6$ \\
\hline 63 & Yaba & 1 & $\% 0.6$ \\
\hline 64 & Kart & 1 & $\% 0.6$ \\
\hline 65 & Gönbe & 1 & $\% 0.6$ \\
\hline 66 & Labis & 1 & $\% 0.6$ \\
\hline Toplam & & 170 & \\
\hline
\end{tabular}

Bazı lakaplar ise kişinin karakterine ithafen, alaycı şekilde verilmiştir. Bu lakaplara örnek olarak Tenten (geveze), muhavven (hain), tülek (kurnaz, uyanık), koneş (fena), çorukçu (inatçı) gibi lakaplar gösterilebilir. Kullanılan lakaplar içerisinde küçük düşürücü lakaplar da azımsanmayacak miktardadır. Deli, cücük, bodur, ayyaş, çıyan, kancık, çirkin, kaba, kart, aygır, kuru, şişik bu tür kullanıma örnektir. Lakap kullanımı günümüzde de yaygın şekilde devam etmektedir. 


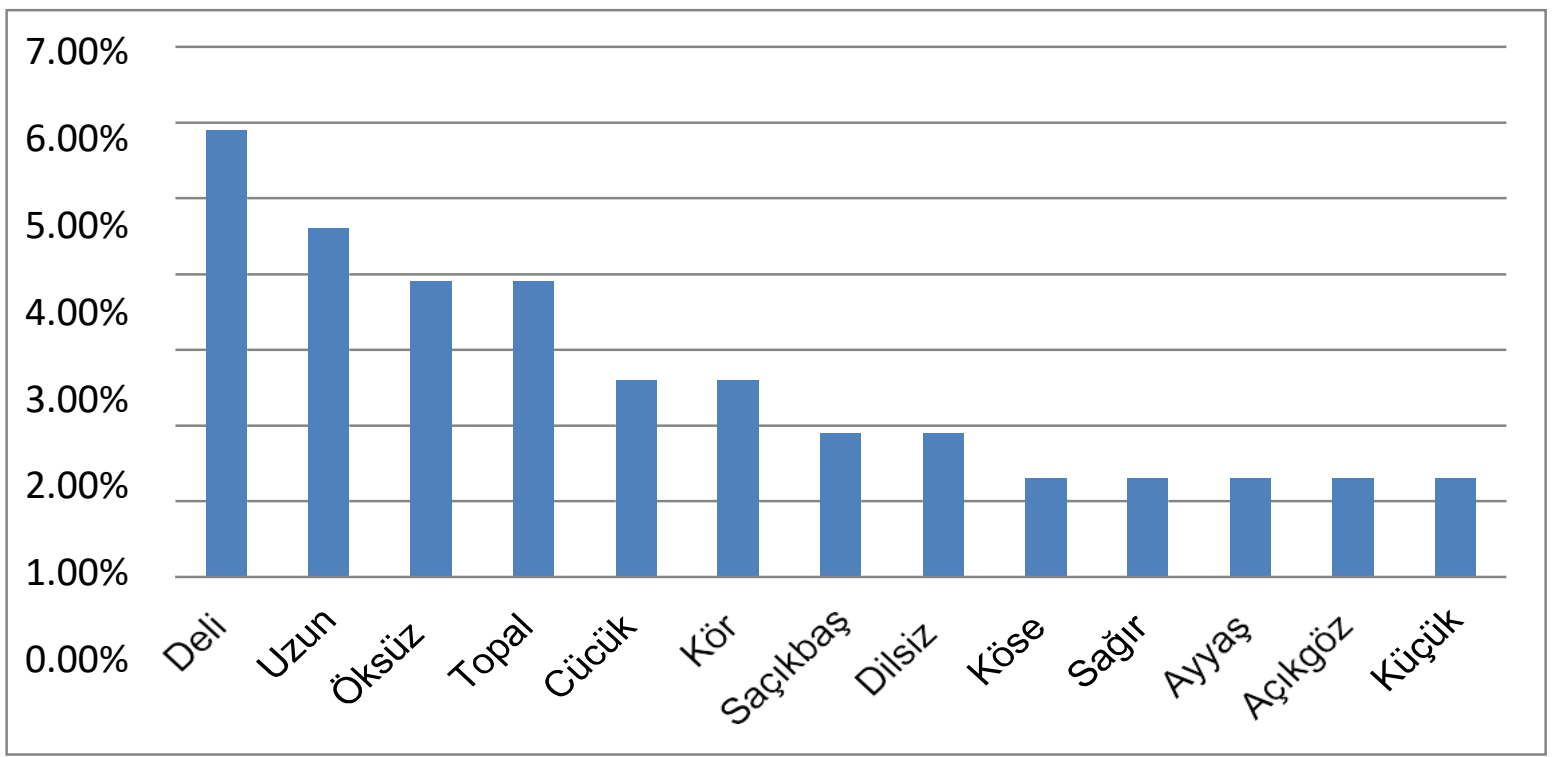

Şekil 4. En sık kullanılan özellik bildiren lakaplar

\subsubsection{Memleket Bildiren Lakaplar}

Memleket bildiren lakaplar kişilerin nereli olduklarını belirtmek amacıyla kullanılan lakaplardır. Yaşadığı bölgeden göç eden insanlar, gittikleri yerlerde kendi vatanlarına vurgu yapan bazı unvanlar kullanmışlardır. Bu lakaplar kişilere yeni geldikleri bölgede ayırt edilmeleri açısından bölgedeki insanlar tarafından verilmiştir. Kişiler göç ettikleri yerde uzun yıllar kalsalar dahi geldikleri coğrafyaya vurgu yapan bu lakaplarla anılmaya devam etmişlerdir.

Tablo 5. Memleket Bildiren Lakaplar

\begin{tabular}{llll}
\hline Sıra No & Kullanılan Lakap & Kullanım Sıklı̆̆ & Kullanım Yüzdesi \\
\hline $\mathbf{1}$ & Taşabadlı & 3 & $\% 25$ \\
\hline $\mathbf{2}$ & Andıranlı & 3 & $\% 25$ \\
$\mathbf{3}$ & Canikli & 2 & $\% 16$ \\
$\mathbf{4}$ & Kışlacıklı & 1 & $\% 8.3$ \\
$\mathbf{5}$ & Ladikli & 1 & $\% 8.3$ \\
$\mathbf{6}$ & Yeniceli & 1 & $\% 8.3$ \\
Toplam & Yozgatlı & 1 & $\% 8.3$ \\
\hline
\end{tabular}

Near East Historical Review 
Tablo 5'te, Akdağ Nahiyesinde kullanılan memleket bildiren lakaplar ve kullanım sıklıkları verilmiştir. Kişilerin memleketlerine vurgu yapan 6 farklı lakap belirlenmiştir. Bu lakaplar 12 hane reisi tarafından kullanılmıştır. Tabloya bakıldığında en fazla kullanılan lakap Taşabadlı lakabıdır. Taşabad, Tanzimat'ın ilk yıllarında Sivas'a bağlı 22 kazadan biridir. 1944'te Tokat'a bağlı kaza olarak teşkilatlandırılmıştır. ${ }^{24} \mathrm{Bu}$ lakabı kullanan kişilerin tamamı nahiyeye bağlı Yenice Karyesinde ikamet etmektedir. Taşabadlı lakabının ardından en çok kullanılan lakaplar sırasıyla Andıranlı ve Canikli'dir. Lakapları kullanan kişilerin Amasya ve Akdağ Nahiyesine yakın yerlerden geldikleri ve buraya yerleştikleri görülmektedir. Amasya dışından gelip yerleşen 1 hane reisi vardır. Yozgadlı lakabını kullanan bu kişi Ziğere Köyü Aşağı Mahalle 44 numaralı hanede ikamet etmektedir. Lakaplardan bölgeye yapılan göçlerin yakın yerlerden olduğu anlaşılmaktadır.

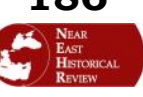

10 / 2

April 2020

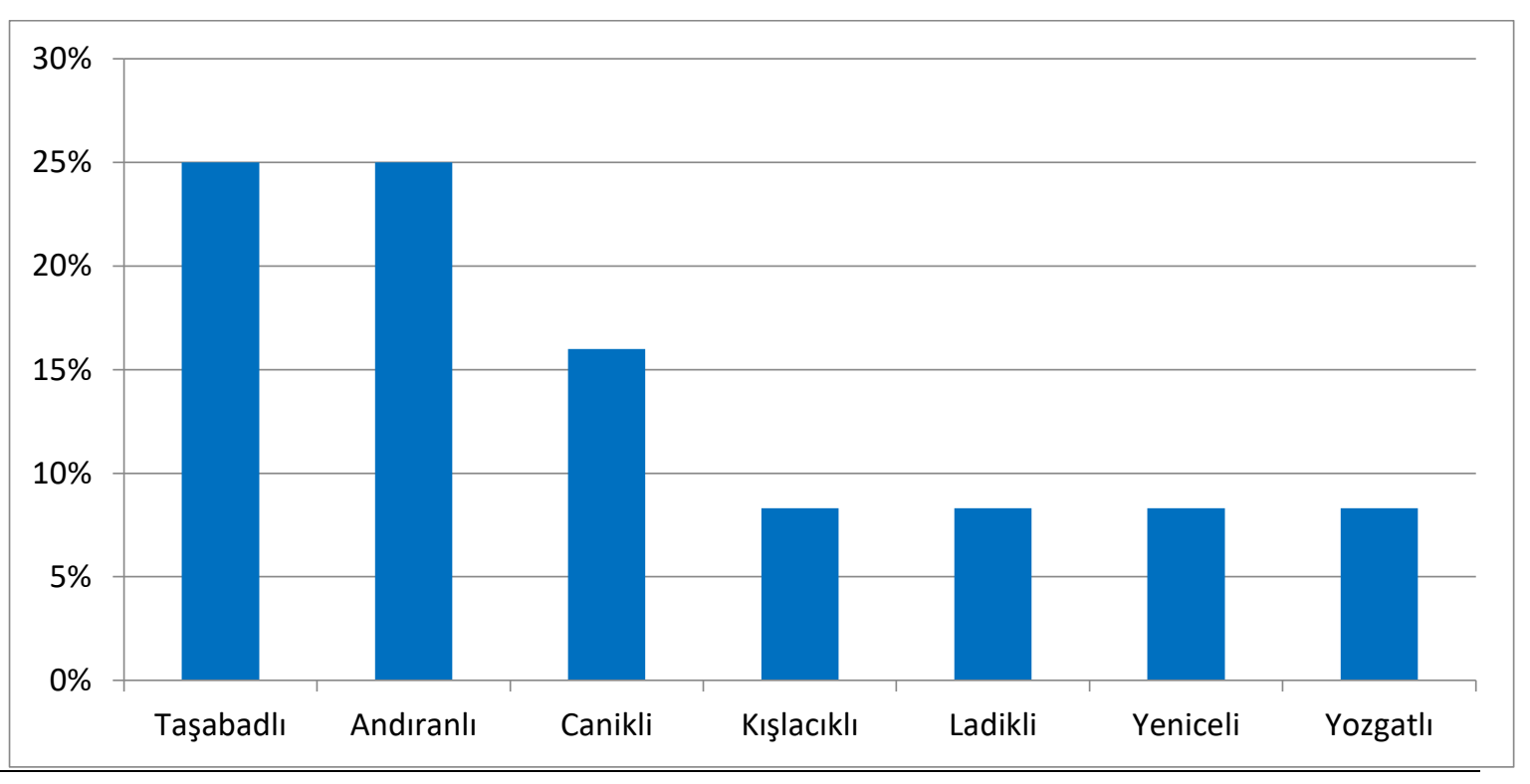

Şekil 5. En sık kullanılan memleket bildiren lakaplar

\subsubsection{Meslek Bildiren Lakaplar}

Akdağ Nahiyesinde 33 farklı meslek bildiren lakap tespit edilmiştir. Bu lakaplar 191 hane reisi tarafından kullanılmıştır. Bunlar içerisinde 79 defa ile en çok Kethüda lakabı kullanılmıştır. Buradaki kullanımının köy işleri ile ilgilenmek olduğu düşünülmektedir. Osmanlı Devleti köy topluluğunun temsilcisi olarak her köyde bir imam ve kethüda bulundurmuştur. ${ }^{25}$

Kethüda lakabı, sivil kuruluşlarda vazifeli kişiler için kullanılan kâhya lakabıyla aynı anlamda kullanılmıştır. Fakat Kethüda lakabı daha çok esnaf teşkilatında görev yapan ve devlet işleriyle ilgilenen kimselerce kullanılmıştır. En üst yöneticilerden en alttakilere kadar herkesin kethüda unvanını taşıyan bir yardımcısı bulunmuştur. ${ }^{26}$ Köyü temsil etmenin yanında bazı işlerle de

\footnotetext{
${ }^{24}$ N. Çavdar, a.g.m., s.208-209.

25 İ. Arslan, a.g.e., s. 73.

${ }^{26}$ Mehmet Canatar, "Kethüda", Diyanet Vakfi Íslam Ansiklopedisi, Cilt:25, Türkiye Diyanet Vakfi Yayınları, 1991, s.332.
}

Near East Historical Review 
ilgilenir, devlet ile köylü arasında köprü görevi görürlerdi. Akdağ Nahiyesinde geçimin tarım ve hayvancılıktan sağlandığı görülmektedir.

Kethüdanın burada köy işleri ile ilgilenen, çitliklerde çalışan kimselerin kullandığı bir lakap olduğu muhtemeldir. Kethüda lakabından sonra en çok kullanılan lakap imam lakabıdır. 21 hane reisi tarafindan kullanılmıştır.

İmam lakabını kullanan hane reislerinin mesleklerine ithafen bu lakabı kullanmışlardır. Ancak tüm hane reislerinin lakaplarıyla mesleklerinin eş olduğu düşünülmemelidir. Örneğin, Merkep Kışlacığı 25 numaralı hanede kayıtlı olan karye imamı İsmail Efendi'nin mesleği rençber olarak yazılmıştır. Yine Karakise Karyesinde 45 numaralı hanede kayıtlı olan Hatip Mustafa Efendi'nin mesleği ziraatçi olarak kaydolunmuştur. Hane reislerinin kendi meslekleri dışında farklı mesleklerle de uğraştıklarıgörülmektedir.

Tablo 6. Meslek Bildiren Lakaplar

\begin{tabular}{llll}
\hline Sıra No & Kullanılan Lakap & Kullanım Sıklı̆̆ & Kullanım Yüzdesi \\
\hline $\mathbf{1}$ & Kethüda & 79 & $\% 41.3$ \\
$\mathbf{2}$ & İmam & 21 & $\% 10.9$ \\
$\mathbf{3}$ & Hatib & 13 & $\% 6.8$ \\
$\mathbf{4}$ & Ayrancı & 13 & $\% 6.8$ \\
$\mathbf{5}$ & Müezzin & 8 & $\% 4.1$ \\
$\mathbf{6}$ & Çavuş & 5 & $\% 2.6$ \\
$\mathbf{7}$ & Çoban & 3 & $\% 1.5$ \\
$\mathbf{8}$ & Onbaşı & 3 & $\% 1.5$ \\
$\mathbf{9}$ & Değirmenci & 3 & $\% 1.5$ \\
$\mathbf{1 0}$ & Berber & 2 & $\% 1.0$ \\
$\mathbf{1 1}$ & Sirkeci & 2 & $\% 1.0$ \\
$\mathbf{1 2}$ & Yağcı & 2 & $\% 1.0$ \\
$\mathbf{1 3}$ & Hıyarcı & 2 & $\% 1.0$ \\
\hline $\mathbf{1 4}$ & Katırcı & 2 & $\% 1.0$ \\
$\mathbf{1 5}$ & Çıkrıçıı & 2 & $\% 1.0$ \\
\hline $\mathbf{1 6}$ & Pekmezci & 1 & $\% 0.5$ \\
$\mathbf{1 7}$ & Çanakçı & 1 & $\% 0.5$ \\
\hline $\mathbf{1 8}$ & Kapucu & 1 & $\% 0.5$ \\
\hline $\mathbf{2 0}$ & Dümbelekçi & 1 & $\mathbf{1}$ \\
\hline & Keçeci & 1 & \\
\hline
\end{tabular}

Near East Historical Review 


\begin{tabular}{llll}
\hline $\mathbf{2 1}$ & Debbağ & 1 & $\% 0.5$ \\
$\mathbf{2 2}$ & Tüccar & 1 & $\% 0.5$ \\
$\mathbf{2 3}$ & Danacı & 1 & $\% 0.5$ \\
$\mathbf{2 4}$ & Davulcu & 1 & $\% 0.5$ \\
$\mathbf{2 5}$ & Sepetçi & 1 & $\% 0.5$ \\
\hline $\mathbf{2 6}$ & Demirci & 1 & $\% 0.5$ \\
$\mathbf{2 7}$ & Çerçi & 1 & $\% 0.5$ \\
\hline $\mathbf{2 8}$ & Lağımcı & 1 & $\% 0.5$ \\
\hline $\mathbf{2 9}$ & Küpçü & 1 & $\% 0.5$ \\
\hline $\mathbf{2 0}$ & Ciğerci & 1 & $\% 0.5$ \\
\hline $\mathbf{3 1}$ & Çıkrıçı & 1 & $\% 0.5$ \\
\hline $\mathbf{3 2}$ & Gazalcı & 1 & $\% 0.5$ \\
\hline $\mathbf{3 3}$ & Balıkçı & 1 & $\% 0.5$ \\
\hline Toplam & & 191 & \\
\hline
\end{tabular}

Temettuat kayıtlarında haneler 1 den başlayarak numaralandırılmıştır. İmam ve muhtarlar öneminden dolayı ilk haneye yazılmışlardır. ${ }^{27}$ Akdağ Nahiyesi temettuat kayıtlarına baktığımızda bu kuralın dışına çıkıldığı görülmektedir. Bazı karye imamlarının 1 nolu haneye yazılmadığı tespit edilmiştir. Örneğin; Karakise Karyesi imamı 42 nolu haneye, Mevrek Köyü imamı 25 nolu haneye, Tadra Köyü imamı 19 nolu haneye, Merkepkışlacığı Köyü imamı 25 nolu haneye, İrni köyü imamı 88 nolu haneye kaydolunmuştur.

İmam lakabından sonra en çok kullanılan lakaplar sırasıyla hatip, ayrancı, müezzin ve çavuş olmuştur.

${ }^{27}$ N. Adiyeke, a.g.m., s.780.

Near East Historical Review 


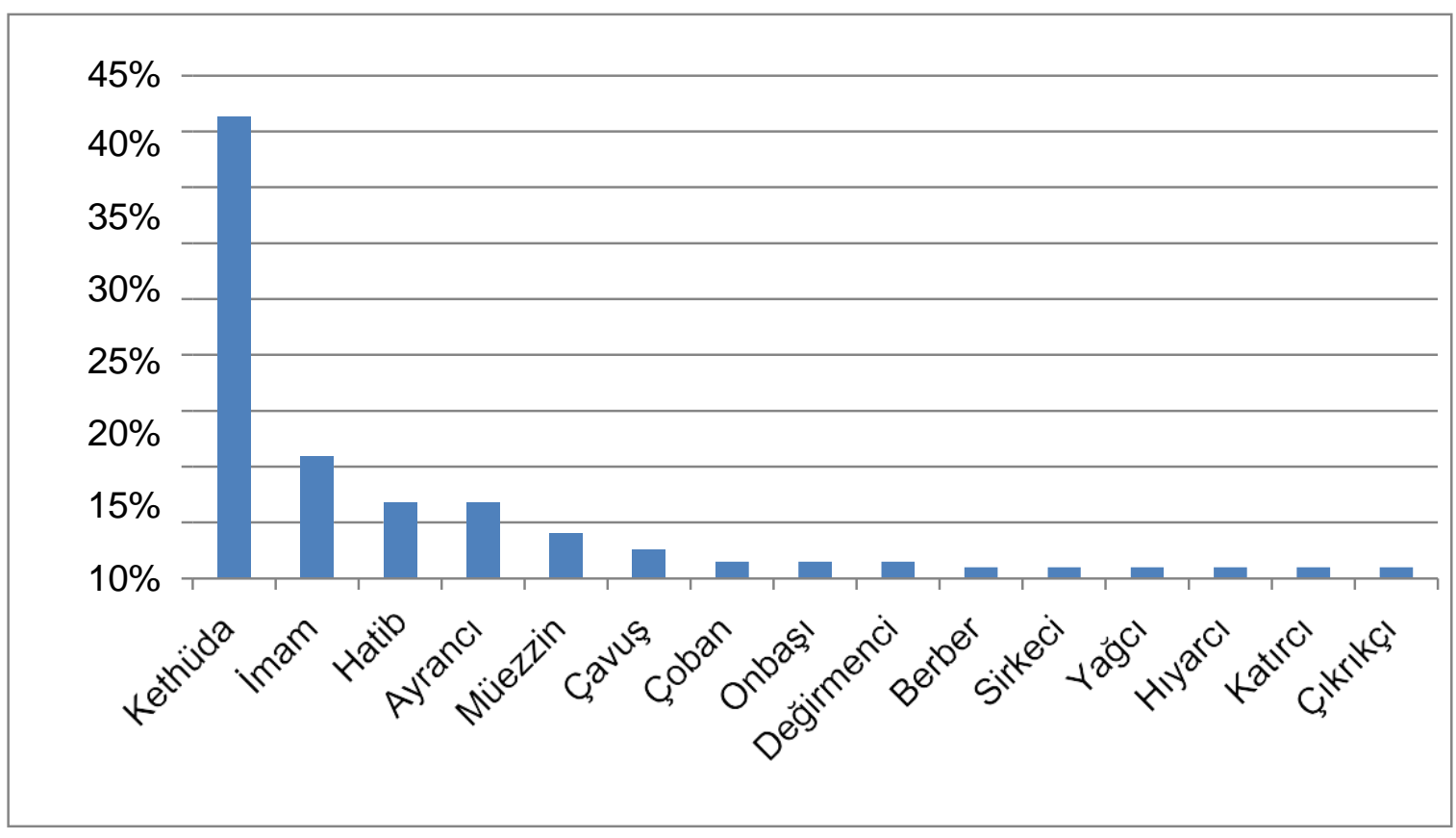

Şekil 6. En sık kullanılan meslek bildiren lakaplar

\subsubsection{Baba İsmi ve Aile İsimlerine Atfen Kullanılan Lakaplar}

Temettuat kayıtlarında hane reislerinin baba ismi, mensup oldukları aile ya da sülaleye ithaf olunan bazı lakaplarla kaydolunduğu görülmektedir. Kaydedilen hane reisinin adı yazılmadan önce, baba adı veya aile adı ardından "oğlu"ibaresi getirilerek bir lakap oluşturulmaktadır. Bu lakap sayesinde hane reislerinin hangi aile ve sülaleye mensup olduğu hakkında önemli bilgiler elde edilmektedir. $\mathrm{Bu}$ şekilde hane reisleri arasındaki akrabalık ilişkileri de tespit edilebilmektedir. Aile adı ile oluşturulan lakap kullanımı günümüzde de devametmektedir.

Akdağ Nahiyesine ait köylerde ikamet eden hane reislerinin kullandıkları baba adı ve aileye mensup 875 lakap tespit edilmiştir. Lakaplar tablo 7 ek 1'de yerleşim yeri ile birlikte verilmiştir. Lakaplardan hane reislerinin fiziki durumları, icra ettikleri meslekler, memleketleri, göçmen olup olmadıkları ile ilgili birçok çeşitli bilgiye ulaşmak mümkündür.

Lakaplardan akrabalık ilişkilerine dair bilgiler elde edilebilmektedir. Karakise Karyesinde Ayrancıoğlu lakabıyla anılan 13 hane reisi bulunmaktadır. Yine aynı karyede Müezzinoğlu lakabıyla 8 hane reisi yazılmıştır. Hane reislerinin aynı karyede ikamet edip aynı lakapla anılmaları aralarındaki akrabalık ilişkisini desteklemektedir. Ancak farklı karyelerde ikamet edip aynı lakapları kullanan hane reislerine de rastlanmaktadır. Taşbaşı Karyesinde kullanılan İlyasoğlu lakabı, Gündüz Karyesinde de 3 hane reisi tarafından kullanılmıştır. Bu kişilerin aynı sülaleye mensup oldukları kuvvetle muhtemeldir. Ancak farklı karyelerde aynı lakabın kullanılması kesin bir akrabalık ilişkisi olduğunu göstermez. Örneğin, İmamoğlu lakabı farklı karyelerde birçok hane reisi tarafindan kullanılmıştır. Karakise Karyesinde 3, Akviran Karyesinde 3, Yenice Karyesinde 3, Başalan Karyesinde 3, İrni Karyesinde 3, Kızseki Karyesinde 1 hane reisi tarafından kullanılmıştır. Burada kişilerin baba mesleklerinden dolayı aynı lakabı kullandıkları kuvvetle muhtemeldir. Yine Müezzinoğlu lakabı, Mevrek Karyesinde bir hane reisi tarafından, Karakise Karyesinde 8 hane reisi tarafından baba mesleklerinden dolayı kullanılmıştır. En çok 
kullanılan lakaplar İmamoğlu, Hatipoğlu, Ayrancioğlu, Müezzinoğlu, Dipioğlu, Köseoğlu, Keleşoğlu, Ustahaliloğlu, Karaköseoğlu, Muharremoğlu, Tongayoğlu, Çolakoğlu, Dağlıoğlu, Alibeşeoğlu, Lafçıŏlu ve İsaoğlu Katanoğlu ve Mustafaoğlu'dur.

\subsection{Temettuat Defterlerinde Kayıtlı Hane Sayısı ve Tahmini Nüfus}

Can, hayat, ruh anlamlarına gelen, Arapça nefs kelimesinin çoğulu olarak kullanılan nüfus kavramı, bir yerde oturmak anlamına da gelmektedir. Daha çok bir coğrafyada yaşayan insanları ifade eder. ${ }^{28}$ Osmanlı Devleti'nin sosyal ve iktisadi yapısı içinde nüfus önemli bir yer tutmuştur. Nüfus konusu ile ilgili çeşitli çalışmalar yapılmış ancak kayda değer çalışmalar ve güvenilir bilgiler Tanzimat döneminde elde edilmiştir. 19. yüzyıla gelindiğinde araştırmacılar, erken döneme ait kaynaklardan elde ettikleri bilgilerle Osmanlı Devleti'nin nüfus yapısı ve özellikleri ile ilgili daha sağlam bilgiler ortaya koymuşlardır.

Sözlükte “yazma, kaydetme” anlamlarına gelen tahrir kelimesi, Osmanlı'da vergilerin ve vergi mükelleflerinin tespiti için yapılan sayımları ve bu sayımların yazıldığı defterleri ifade eder ${ }^{29}$ Osmanlı Devleti'nin nüfus araştırmaları içerisinde çok eskiden beri yapılmakta olan tahrirler önemli bir yer tutmaktadır . ${ }^{30}$

Tahrirlerin amacı, halkın ikamet ettiği yerleri, sahip oldukları mal ve ürünlerin kaynaklarını, tımar sahiplerinin gelirlerini, halk ve tımar sahipleri arasındaki sorunları hükümdara bidirmektir. Yine hane sayılarının belirlenerek kanuna aykırı vergi alımının önüne geçmek istenmiştir. Sayımların titizlikle yapılması, kişilerin ve gelir getiren herşeyin eksiksiz yazılması en önemli hususlardır. ${ }^{31}$

Tahrirler, Osmanlı Devleti'nin tımar sistemini uyguladığı bölgelerde, vergiye konu olan ekonomik faaliyetleri ve vergi mükelleflerinin yerinde tespiti açısından önemli olmuştur ${ }^{32}$. Tahrirler, Devlet sınırları içerisinde yer alan köy ve kasaba nüfusunun belirlenmesi, toprak miktarı, kişilerin ödedikleri vergiler gibi birçok bilgiye ulaşılabilme imkanı sağlamaktadır. ${ }^{33}$

Tımar sisteminin zamanla önemini yitirmesi iletahrir usülü terk edilmeye başlanmıştır. Daha önce olağanüstü hal durumlarında alınan avarız vergisinin sürekli hale getirilmesi ile bu vergiyi ödemekle yükümlü kimselerin sayımına başlandı. ${ }^{34}$ Avarız defterleri bir sonraki nüfus sayımlarının öncülüğünü yapmıştır. ${ }^{35}$

Lügatta ev, bina ikametgah gibi anlamlara gelen hane deyiminin nüfus meselesi ve tahrirlerle ilgili yapılan çalışmalarda tam olarak ne ifade ettiği, kaç kişilik bir aileyi temsil ettiği konusu

\footnotetext{
${ }^{28}$ Yunus Koç, "Nüfus", Türkiye Diyanet Vakfi İslam Ansiklopedisi, Cilt:33, Türkiye Diyanet Vakfı Yayınları, 2007, s.293.

${ }^{29}$ Mehmet Öz, "Tahrir”, Türkiye Diyanet Vakfi İslam Ansiklopedisi, Cilt:39, Türkiye Diyanet Vakfı Yayınları, 2010, s.426.

${ }^{30}$ Numan Elibol, “Osmanlı İmparatorluğu'nda Nüfus Meselesi ve Demoğrafi Araştırmaları”, Süleyman Demirel Üniversitesi İktisadi ve İdari Bilimler Fakültesi Dergisi, Sayı:12, 2007, s.136- 137.

${ }^{31}$ M. Öz, a.g.m., s.426.

32 Oktay Özel, “Avarız ve Cizye Defterleri”, Editör: H. İnalcık ve Ş. Pamuk, Osmanlı Devleti’nde Bilgi ve İstatistik, Ankara 2000, s.3.

${ }^{33}$ Adnan Çimen, “ Sayım Kayıt Düzeni ve Teşkilatlanma Açısından Osmanlı Nüfus Hizmetleri”, Gazi Üniveristesi İktisadi ve idari Bilimler Fakültesi Dergisi, 2012, s.191.

${ }^{34}$ Mehmet Güneş, “ Osmanlı Dönemi Nüfus Sayımları ve Bu Sayımları İçeren Kayıtların Tahlili”, Akademik Bakış, 2014, s.221.

${ }^{35}$ Salim Özcan, "H.1256 (1840) Tarihli Amasya Nüfus Defterleri ile H.1260-1261(1844- 1845) Tarihli Amasya Temettuat Defterlerinin Karşılaştırmalı Değerlendirilmesi, Studies of The Otoman Domain,2016, s.98.
} 
halen tartışılmakta olan bir kavramdır. ${ }^{36}$ Vergi kaynaklarının yazıldığı defterlerde hane, çoğunlukla aileyi temsil eden kocanın adıyla yazılmıştır. ${ }^{37}$

1768 tarihli Avarız defterine göre Akdağ Nahiyesinin nüfusu 1650-2200 arasındadır. Yine 1831 'de yapılan sadece erkeklerin sayıldığı nüfus sayımında Akdağ, Ezinepazar ve Geldiklan Nahiyelerinin toplam nüfusu 2983 olarak kaydedilmiştir. Bu toplam içerisinde 134 gayrimüslim sayılmıştır. ${ }^{38}$ Akdağ Nahiyesi nüfusunun tamamının Müslümanlardan oluşmadığı görülmektedir. Nitekim temettuat belgelerinden elde edilen bilgilerde de Akdağ Nahiyesine bağlı köylerde gayrimüslim hane reislerinerastlanmaktadır.Hane nüfusunun belirlenmesinde, vergi kayıtlarından yola çıkarak yapılan nüfus tahminlerine ulaşmak için Ömer Lütfi Barkan tarafından her hanenin beş kişiden oluştuğu görüşü kabul edilmiştir. ${ }^{39}$ Akdağ Nahiyesine ait temettuat defterlerinde 918 hane tespit edilmiştir. Hanenin beş kişiden oluştuğu formülü kullanılarak yapılan hesaplama sonucunda 19. yüzyıl ortalarında Akdağ Nahiyesinin tahmini nüfusu 4690 kişidir.

Tablo 7 incelendiğinde en fazla nüfusa sahip olan Ziğere Köyü Yukarı Mahalle'dir. Ziğere'nin temettuat defterinde hane sayısının 151 olduğu tespit edilmiştir. Hane sayısının beş sayısı ile çarpımı sonucunda karyenin tahmini nüfusunun 755 kişi olarak hesaplanmıştır. Ziğere Karyesinden sonta nüfusu en kalabalık olan karye Yenice Karyesi'dir. Yenice'nin hane sayıs1 127 'dir. Tahmini nüfusu ise 635 kişidir. Akdağ Nahiyesinde en az nüfusa sahip olan karye Kocaköy'dür. Kocaköy Karyesinde temettuat defterine kayitl 3 hane tespit edilmiştir. Bu 3 hanenin beş sayısı ile çarpımı sonucunda ise karyenin tahmini nüfusu 15 olarak hesaplanmıştır. Tablodaki veriler tahmini verilerdir.

Tablo 7.1845 Yılına Ait Hane Sayısı ve Tahmini Nüfus

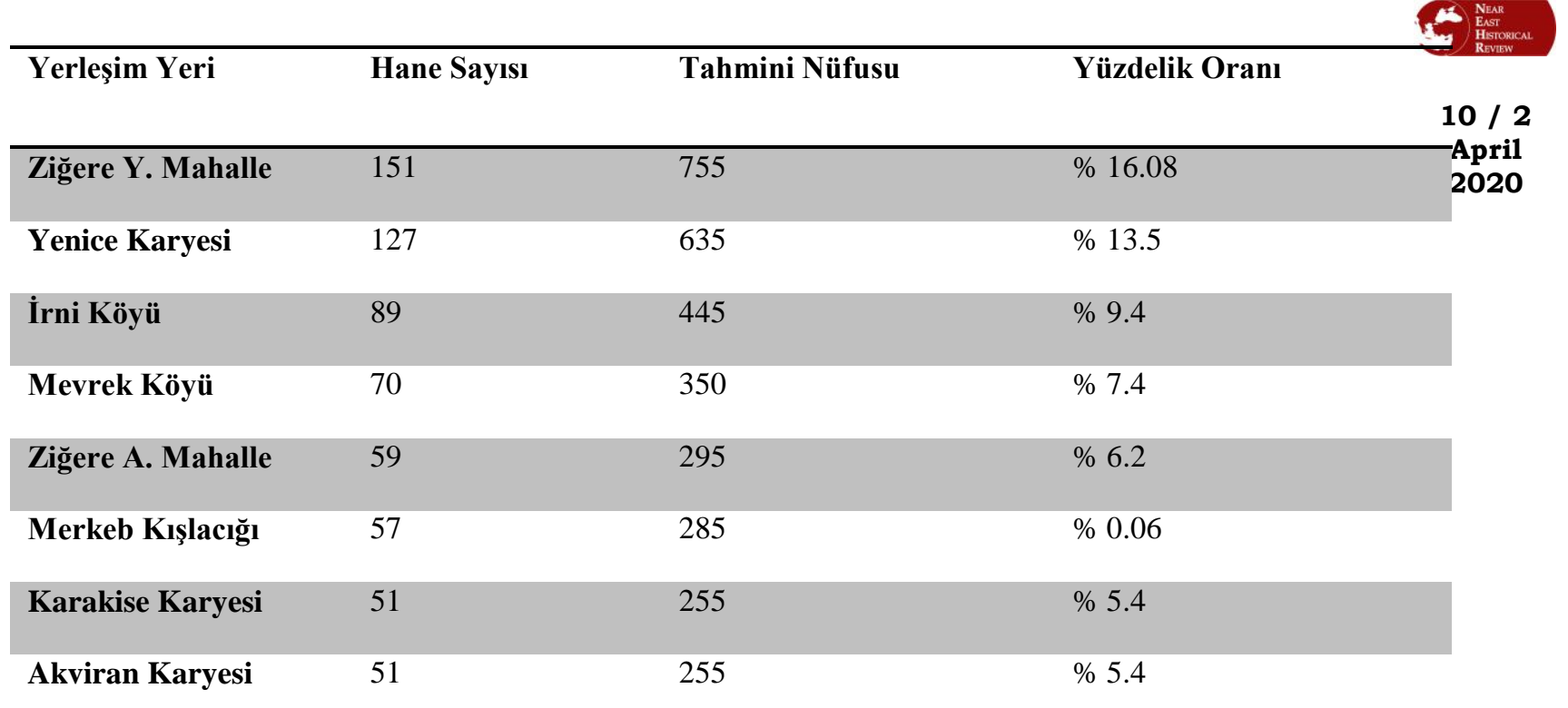

\footnotetext{
${ }^{36}$ Nejat Göyünç, "Hane Deyimi Hakkında", Tarih Dergisi, 1979, s.331.

${ }^{37}$ S .Kurt, a.g.m., s.31.

${ }^{38}$ Salih Kahriman-Fevzi Gür, Amasya Nüfus Defterleri 1840, 2012, s.27-28.

${ }^{39}$ Said Öztürk, “ XIX. Yüzyılda Söğüd'ün Sosyo-Ekonomik Yapısı”, Türk Dünyası Tarih Dergisi, 1995, s.36.
} 


\begin{tabular}{|c|c|c|c|}
\hline Ziğere Soğukpınar & 43 & 215 & $\% 4.5$ \\
\hline Seracık Karyesi & 30 & 150 & $\% 3.1$ \\
\hline Başalan Karyesi & 28 & 140 & $\% 2.9$ \\
\hline Yıkılkan Karyesi & 27 & 135 & $\% 2.8$ \\
\hline Gündüz Karyesi & 25 & 125 & $\% 2.6$ \\
\hline Boyalı Karyesi & 25 & 125 & $\% 2.6$ \\
\hline Tadra Köyü & 23 & 118 & $\% 2.5$ \\
\hline Kızseki Karyesi & 20 & 100 & $\% 2.1$ \\
\hline Sarılar Karyesi & 12 & 60 & $\% 1.2$ \\
\hline Sofular Karyesi & 11 & 55 & $\% 1.1$ \\
\hline Aktaş Karyesi & 9 & 45 & $\% 0.9$ \\
\hline Kozalan Karyesi & 7 & 35 & $\% 0.7$ \\
\hline Siga Karyesi & 6 & 30 & $\% 0.6$ \\
\hline Kürtler Karyesi & 6 & 30 & $\% 0.6$ \\
\hline Taşbaşı Karyesi & 4 & 20 & $\% 0.4$ \\
\hline Çukurviran & 4 & 20 & $\% 0.4$ \\
\hline Kocaköy & 3 & 15 & $\% 0.3$ \\
\hline Toplam & 938 & 4690 & $\% 100$ \\
\hline
\end{tabular}

\subsection{Akdağ Nahiyesinde Hane Reislerine Ait Meslekler}

Meslek kişinin hayatı boyunca yaşamsal faaliyetlerini yerine getirebilmesi, geçimini sağlayabilmesi, toplum içerisinde kendine bir yer bulabilmesi için uğraştığı birtakım faaliyetler bütünüdür. Kişinin toplumdaki statüsünden, insan ilişkilerinden, yaşadığı yer seçimine kadar birçok şeye etki etmektedir. ${ }^{40} \mathrm{Kişinin} \mathrm{icra} \mathrm{ettiği} \mathrm{mesleği} \mathrm{onun} \mathrm{yaşamının} \mathrm{bir} \mathrm{parçasıdır.} \mathrm{Kendi} \mathrm{ilgi}$ ve yetenekleri doğrultusunda gelişir. Ancak yaşadığ ${ }_{1}$ coğrafya, bulunduğu toplumun gelişmişlik düzeyi ve hangi mesleklerin geliştiği de bunun belirlenmesinde önemlidir.

${ }^{40}$ Said Öztürk, XIX. Yüzyılda Söğüd'ün Sosyo-Ekonomik Yapısı, Türk Dünyası Tarih Dergisi, İstanbul Kitabevi, 1996, s.87. 
Temettuat belgeleri 1şığında elde edilen en önemli bilgilerden biri de hane reislerinin icra ettiği mesleklerdir. Kişilerin mesleklerinden yola çıkarak bölgedeki ekonomik faaliyetlerin neler olduğu, hangi zanaat kollarının geliştiği ile ilgili bazı bilgilere ulaşılabilmektedir.

Akdağ Nahiyesinde icra edilen meslekler ve köylere göre dağılımı tablo 10 'da gösterilmektedir. Kayıtlardan elde edilen bilgilere göre 918 hanenin tamamının meslekleri belirtilmemiştir. Bir meslek icra edecek durumda olamayanlar önemsenmiş ve meslek kısmına bunu açıklayan bir bilgi yazılmıştır. Örneğin, Merkepkışlacığı Karyesinde 56 nolu hanede ikamet eden Topal Mustafa oğlu Abdurrahman'ın mesleği belirtilmemiştir. Meslek kısmına "merkumun mecruh olduğu" ibaresi yazılmıştır. Yaralı anlamına gelen mecruh kelimesinin kullanılması, adı geçen kişinin bedensel bir sakatlığ ya da eksikliğinin bulunduğuna işaret etmektedir. Yine adı geçen köyde 57 nolu hanede ikamet eden hane reisinin mesleğinin yazılmadığı, bunun yerine "fukaradan olduğu" ibaresinin yazıldığı görülmektedir. Temettuat defterlerinde sakat ve çalışamaz kişiler dışında yaşlılar, sabiler ve yetimler de bir meslek icra edemeyecek durumda olan kişiler olarak belirtilmişlerdir. Meslek icra edemeyen ve neden meslek icra edemedikleri açıllanan hane reislerinden ödemekle yükümlü oldukları vergi alınmamıştır.

Tablo 8. Hane Reislerine Ait Mesleklerin Köylere Göre Dağılımı

\begin{tabular}{|c|c|}
\hline Meslekler & Sayısı \\
\hline \multicolumn{2}{|l|}{ Kocaköy } \\
\hline Ziraatçi & 3 \\
\hline \multicolumn{2}{|c|}{ Ziğere Soğukpınar Karyesi } \\
\hline Bahçıvan & 27 \\
\hline İmam & 1 \\
\hline Muhtar & 1 \\
\hline Hatib & 1 \\
\hline Amele & 1 \\
\hline Çoban & 1 \\
\hline Harir çekici esnafı & 1 \\
\hline Mesleği Belirtilmeyen & 9 \\
\hline \multicolumn{2}{|l|}{ Siga Karyesi } \\
\hline Ziraatçi & 4 \\
\hline Rençber & 1 \\
\hline Çoban & 1 \\
\hline
\end{tabular}




\section{Sofular Karyesi}

Ziraatçi 11

Taşbaşı Karyesi

\begin{tabular}{ll} 
Ziraatçi & 3 \\
Bahçıvan & 1 \\
Gündüz Karyesi & \\
\hline Ziraatçi & 21 \\
Hizmetkar & 2 \\
\hline Kizir & 1 \\
\hline Sabi & 1 \\
\hline
\end{tabular}

\section{Başalan Karyesi}

Ziraatçi 25

Çoban

3

$10 / 2$

April

Yenice Karyesi

2020

\begin{tabular}{ll} 
Bahçıvan & 107 \\
Irgat & 8 \\
Çoban & 5 \\
Sakat & 1 \\
Hizmetkar & 1 \\
Kizir & 1 \\
Amil & 1 \\
\hline Amelmande & 1 \\
\hline Sabi & 1 \\
\hline İrni Köyü & \\
\hline Rençber & 74 \\
Hizmetkar & 4 \\
\hline Irgat & 3 \\
\hline Bilasınıf & 2 \\
\hline İmam & 1 \\
\hline
\end{tabular}

Near East Historical Review 


\begin{tabular}{|c|c|}
\hline Derviş & 1 \\
\hline Mesleği Belirtilmeyen & 7 \\
\hline \multicolumn{2}{|l|}{ Seracık Karyesi } \\
\hline Rençber & 26 \\
\hline Çoban & 2 \\
\hline Mesleği Belirtilmeyen & 2 \\
\hline \multicolumn{2}{|l|}{ Merkeb Kışlacığı } \\
\hline Ziraatçi & 30 \\
\hline Irgat & 10 \\
\hline Çoban & 3 \\
\hline Bahçıvan & 3 \\
\hline Rençber & 2 \\
\hline Sabi & 2 \\
\hline Hatib & 1 \\
\hline Oduncu & 1 \\
\hline Mecruh & 1 \\
\hline Fukara & 1 \\
\hline Asakir-i Nizamiye & 1 \\
\hline Mesleği Belirtilmeyen & 1 \\
\hline \multicolumn{2}{|l|}{ Mevrek Köyü } \\
\hline Rençber & 51 \\
\hline Ziraatçi & 15 \\
\hline Çoban & 1 \\
\hline Harir keşide & 1 \\
\hline İmam & 1 \\
\hline \multicolumn{2}{|l|}{ Sarılar Karyesi } \\
\hline Ziraatçi & 12 \\
\hline \multicolumn{2}{|l|}{ Tadra Köyü } \\
\hline Ziraatçi & 19 \\
\hline Çoban & 2 \\
\hline
\end{tabular}




\begin{tabular}{ll}
\hline İmam & 1 \\
Mesleği Belirtilmeyen & 1 \\
Kızseki Karyesi & \\
\hline Ziraatçi & 19 \\
Karakise Karyesi & \\
& \\
Ziraatçi & 37 \\
Çoban & 7 \\
İmam & 1 \\
Mesleği Belirtilmeyen & 1
\end{tabular}

\section{Kozalan Karyesi}

Ziraatçi

Yıkılkan Karyesi

$\begin{array}{lr}\text { Bahçıvan } & 14 \\ \text { Ziraatçi } & 5 \\ \text { Çoban } & 5 \\ \text { Mesleği Belirtilmeyen } & 2\end{array}$

\section{Ziğere Yukarı Mahalle}

\begin{tabular}{ll} 
Bahçıvan & 108 \\
Çoban & 6 \\
Rençber & 5 \\
Amele & 3 \\
Amil & 3 \\
Hizmetkar & 2 \\
Matbaaci & 2 \\
Berber & 1 \\
İmam & 1 \\
Sabi & 1 \\
Mesleği Belirtilmeyen & 5 \\
\hline
\end{tabular}

Near East Historical Review 


\begin{tabular}{lc}
\hline Çukurviran & \\
& 3 \\
Ziraatçi & 1
\end{tabular}

\section{Ziğere Aşağı Mahalle}

$\begin{array}{ll}\text { Bahçıvan } & 48 \\ \text { Sabi } & 3 \\ \text { Amil } & 2 \\ \text { Harir keşide ustası } & 2 \\ \text { Derviş } & 2 \\ \text { Hatib } & 1 \\ \text { Mesleği Belirtilmeyen } & 3\end{array}$

\section{Kürtler Karyesi}

\begin{tabular}{lc} 
Ziraatçi & 5 \\
Hizmetkar & 1 \\
Aktaş Karyesi & \\
\hline Ziraatçi & 8 \\
Çoban & 1 \\
\hline
\end{tabular}

\section{Boyalı Karyesi}

\begin{tabular}{lc} 
Rençber & 24 \\
Çoban & 1 \\
Akviran Karyesi & \\
\hline Ziraatçi & 43 \\
Hizmetkar & 3 \\
İmam & 1 \\
Keresteci & 1 \\
\hline Çoban & 1 \\
\hline
\end{tabular}

Near East Historical Review 


\begin{tabular}{ll}
\hline Kizir & 1 \\
Mesleği belirtilmeyen & 1 \\
Toplam & 916 \\
\hline
\end{tabular}

Tablo 8'de görüldüğü üzere hane reisleri ziraata dayalı mesleklerle uğraşmışlardır. Hane reislerinin genellikle bahçıvanlık, rençberlik, çobanlık, 1rgadlık, ziraatçılık ve hizmetkârlık gibi mesleklerle ilgilendikleri görülmektedir.

Tablo 9.Hane Reislerine Ait Mesleklerin Toplam Dağılımı

\begin{tabular}{|c|c|c|c|}
\hline Sira No & Meslekler & Toplam Mevcudu & Dağılım Yüzdesi \\
\hline 1 & Bahçıvan & 310 & $\% 97.4$ \\
\hline 2 & Ziraatçi & 267 & $\% 83.9$ \\
\hline 3 & Rençber & 182 & $\% 57.2$ \\
\hline 4 & Çoban & 40 & $\% 12.5$ \\
\hline 5 & Mesleği belirtilmeyen & 33 & $\% 10.3$ \\
\hline 6 & Irgat & 21 & $\% 6.6$ \\
\hline 7 & Hizmetkar & 13 & $\% 4.08$ \\
\hline 8 & Sabi & 9 & $\% 2.8$ \\
\hline 9 & İmam & 7 & $\% 2.2$ \\
\hline 10 & Amil & 5 & $\% 1.5$ \\
\hline 11 & Amele & 4 & $\% 1.2$ \\
\hline 12 & Harir Keşide & 4 & $\% 1.2$ \\
\hline 13 & Hatib & 3 & $\% 0.9$ \\
\hline 14 & Kizir & 3 & $\% 0.9$ \\
\hline 15 & Derviş & 3 & $\% 0.9$ \\
\hline 16 & Matbaacı & 2 & $\% 0.6$ \\
\hline 17 & Bilasınıf & 2 & $\% 0.6$ \\
\hline 18 & Muhtar & 1 & $\% 0.3$ \\
\hline 19 & Berber & 1 & $\% 0.3$ \\
\hline 20 & Oduncu & 1 & $\% 0.3$ \\
\hline
\end{tabular}

Near East Historical Review 


\begin{tabular}{llll}
$\mathbf{2 1}$ & Keresteci & 1 & $\% 0.3$ \\
$\mathbf{2 2}$ & Amelmande & 1 & $\% 0.3$ \\
$\mathbf{2 3}$ & Sakat & 1 & $\% 0.3$ \\
$\mathbf{2 4}$ & Fukara & 1 & $\% 0.3$ \\
$\mathbf{2 5}$ & Mecruh & 1 & $\% 0.3$ \\
$\mathbf{2 6}$ & Asakir-i Nizamiye & 1 & $\% 0.3$ \\
$\mathbf{2 7}$ & Yetim ve sabi & 1 & $\% 0.3$ \\
Toplam & & 918 & $\% 100$ \\
\hline
\end{tabular}

Tarla tarımına göre, bağ ve bahçe işleri daha fazla emek ister. Bu yüzden genellikle yoğun nüfuslu yerlerde yaygınlaşmıştır. ${ }^{41}$ Üretim ise daha çok bahçıvan ve hizmetkârlarla sağlanmıştır. ${ }^{42}$

Tablo 9'da Akdağ Nahiyesinde ikamet eden hane reislerinin icra etmiş oldukları mesleklerin toplam dağılımı verilmektedir. Akdağ Nahiyesinde en fazla icra edilen meslek bahçıvanlıktır. Bunun sebebi, bağcılık ve dut yetiştiriciliğinin bu bölgede yaygın olmasıdır. Hane reislerinden 310 kişi bahçıvanlık mesleğini yapmaktadır. Bu mesleğin yapanların çoğu üzüm ve dut bağlarında çalışmaktadır. ${ }^{43}$ Bahçıvanlık mesleğini icra edenlerin büyük çoğunluğu Ziğere Karyesi Yukarı Mahallede ikamet etmektedir. Ziğere 152 hane sayısı ile Akdağ Nahiyesinin en kalabalık karyesidir. Böylece, bahçıvanlığın yoğun nüfuslu yerlerde yapıldığı bilgisi desteklenmektedir. Bahçıvanlıktan sonra en çok yapılan meslek ziraatçılıktır. 267 hane reisi ziraatçı olarak kaydedilmiştir. Ziraatçıllktan sonra ise en fazla rençberlik mesleği icra edilmiştir. 182 hane reisi rençber olarak yazılmıştır. Rençber, kendi tarım arazisinde ziraatla uğraşan çiftçidir. ${ }^{44}$ Rençberlikten sonra en çok yapılan meslek çobanlıktır.40 hane reisi çoban olarak kaydedilmiştir. Tarımdan sonra hayvancılığın meslekler üzerinde önemli olduğu görülmektedir.

Hane reislerinin mesleklerinin köylere göre dağılımına baktığımızda, çoğunun aynı mesleği icra ettiği görülmektedir. Böylece köyler ve köyde yaşayanlar arasında ekonomik ve sosyal büyük farkların olmadığı anlaşılmaktadır. Meslekler içerisinde esnaf ve zanaatkârlar yok denecek kadar azdır. Bu durum tarım ve hayvancılığın birincil ekonomik faaliyetler olması ile ilgilidir. Sadece beş kişinin tarım dışı meslek icra ettikleri görülmüş̧ür. Ziğere Karyesinde ikamet eden 91 ve 110 nolu hane reislerinin mesleği matbaacı, 118 nolu hane reisinin mesleği berberlik olarak kaydedilmiştir. AkviranKaryesinde ikamet eden 45 nolu hane reisinin mesleği keresteci, Merkepkışlacı ğı Karyesinde ikamet eden 51 nolu hane reisinin mesleği oduncu ve 57 nolu hane reisinin mesleği "asakir-i nizamiyeden olduğu” ş̧eklinde kaydedilmiştir. Bu kişinin ordu mensubu olduğu anlaşılmaktadır.

Mesleklerin genel dağılımı içerisinde mesleği belirtilmeyen kişi sayısı 33'tür.Bu kişilerin mesleklerinin ne olduğu ile ilgili tahminde bulunulabilecek bir bilgi verilmemiştir. Kayıtlarda 21

\footnotetext{
${ }^{41}$ Tevfik Güran, 19. Yüzyıl Osmanlı Tarımı Üzerine Araştırmalar, Eren Yayıcılık, İstanbul, 1998, s. 80.

${ }^{42}$ Rıza Yıldırım, Temettuat Defterlerine Göre Geldiklan Nahiyesi'nin Sosyal ve Ekonomik Durumu, Yayımlanmamış Yüksek Lisans Tezi, Amasya Üniversitesi Üniversitesi Sosyal Bilimler Enstitüsü, Amasya 2017, s.42.

${ }^{43}$ Tayfun Soydal, Temettuat Defterlerine Göre Ezinepazar Nahiyesinin Sosyal ve Ekonomik Durumu, Yayımlanmamış Yüksek Lisans Tezi, Amasya Üniversitesi Sosyal Bilimler Enstitüsü, Amasya 2018, s.28.

${ }^{44}$ İ. Çağlar, a.g.m., s.422.
}

\section{Near East Historical Review}


hane reisinin mesleği ırgad olarak kaydedilmiştir. Irgadlık, tarımla ve tarım dışı bazı işlerde çalışan kişiler için kullanılmaktadır. Rençberden farklı olarak, çalıştı̆ğ tarım arazisinin sahibine bağlıdır ve günlük yevmiye karşılığında uzun süre aynı topraklarda çalışır. ${ }^{45}$ En çok icra edilen mesleklerden biri de hizmetkârlık olmuştur. 13 hane reisi hizmetkâr olarak kaydedilmiştir. Hizmetkârlık mesleğini icra edenlerin tam olarak ne yaptıkları bilinmese de, bu kişilerin evlerde hane sahiplerinin günlük yemek, temizlik vs. gibi işlerini yapan kişiler olması tahmin edilmektedir. ${ }^{46}$ Kayıtlarda 7 hane reisinin imamlık mesleğini icra ettiği görülmektedir. Nahiye içerisinde bazı köylerin imamlarının bulunmadığı görülmektedir. Din işlerinin imamın olmadığı bu köylerde, bilgi sahibi tecrübeli kimselerce yapıldığg kuvvetle muhtemeldir.

Akdağ Nahiyesi içerisinde 5 hane reisi amil, 4 hane reisi amele olarak kaydedilmiştir. $\mathrm{Bu}$ kişiler, belirli bir ücret karşılığında tarım, inşaat vs. gibi yerlerde çalışan işçilerdir. ${ }^{47}$ Nahiye içerisinde 3 hane reisinin mesleği kizir olarak kaydedilmiştir. Kizir, köy muhtarının yardımcısıdır.

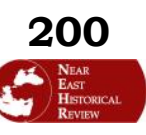

$10 / 2$

April 2020

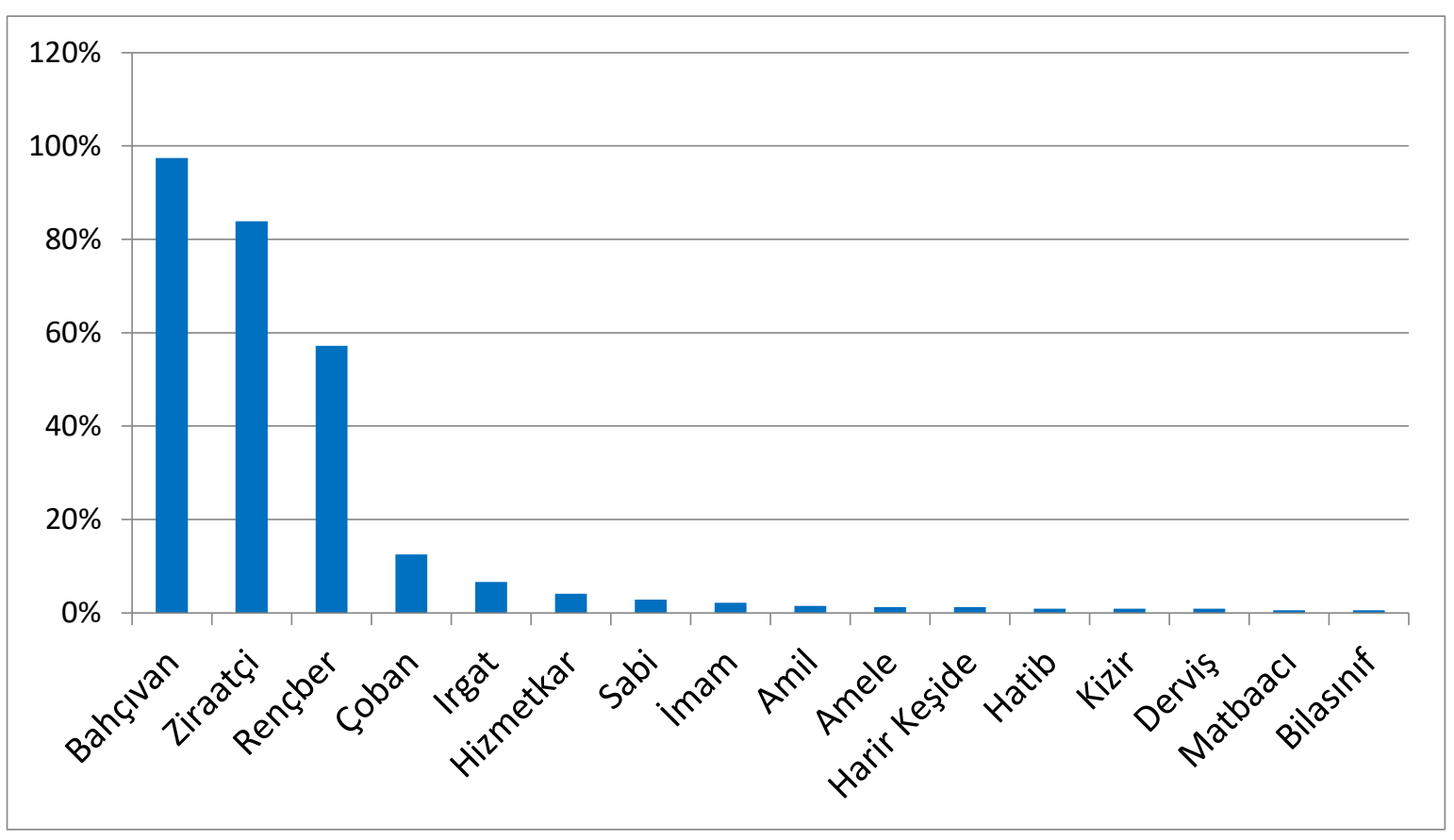

Şekil 7. Mesleklerin toplam dağılım

45 İ. Çağlar, a.g.m., s.422.

${ }^{46}$ Z. Özlü, a.g.e., s.164.

${ }^{47}$ Z. Özlü, a.g.e., s.164.

Near East Historical Review 


\section{SONUÇ}

Temettuat kayıtları kullanılarak yapılan bu çalışma sonucunda, 19. yüzyıl ortalarında Sivas Eyaleti, Amasya Sancağına bağlı Akdağ Nahiyesinde 26 köy, 938 hane bulunmakta ve 4690 kişi ikamet etmektedir. Amasya' ya ait diğer temettuat çalışmaları (Geldiklan, Hakala, Ezinepazar) ile karşılaştırıldığında nüfus bakımından en büyük nahiye Akdağ Nahiyesi'dir. Nahiyenin en kalabalık köyü 151 hane sayısı ile Ziğere Yukarı Mahalle'dir. Nahiye nüfusu içerisinde sadece 13 gayrimüslim hane reisi ismine rastlanmıştır. Nahiyenin tamamına yakını Müslüman'dır.

Defterlere nahiyede ikamet eden hane reislerinin isimleri, lakapları, unvanları ile birlikte yazılmıştır. Bu bilgilerle kişilerin icra ettikleri meslekler, memleketleri, fiziksel özellikleri, sosyal statüleri, akrabalık ilişkileri gibi birçok bilgiye ulaşılmıştır. Kişilerin nereli oldukları memleketlerine ithafen kullandıkları lakaplardan yola çıarak tespit edilmiştir ve yakın yerlerden göç ettikleri anlaşılmıştır. Aile ve baba isimlerine atfen kullanmış oldukları lakapları ile akrabalık bağları tespit edilmiştir. Kullanılan isimlerden hareketle dinin sosyal hayat üzerindeki etkisinin isimler aracılığ ile devam ettirildiği görülmektedir . Elde edilen bilgilerden yola çıkılarak, sosyal yaşam üzerinde önemli ekonomik faaliyetler olan tarım ve hayvancıllğın etkisini görmek mümkündür.

\section{KAYNAKLAR}

\section{Arşiv Vesikaları}

Cumhurbaşkanlığı Osmanlı Arşivi (BOA.), Maliye Varidat Muhasebesi Temettuat Defterleri (ML.VRD.TMT.) genel koduyla kayıtlı Akdağ Nahiyesine ait 12822, 12824, 12828, 12831, $12833,12843,12851,12865,12867,12870,12877,12878,12882,12883,12887,12889$, 12901, 12903, 12907, 12909, 12910, 12913, 12966, 12972, 12981, 13028, numaralı defterler.

\section{Kitap ve Makaleler}

Açık,Turan, "Bey”likten “Ağa”llğa: 17. Yüzyılın İlk Yarısında Trabzon'da “Unvan Enflasyonu”, Karadeniz Incelemeleri Dergisi, 2014, ss.12-37.

Adıyeke, Nuri, "Temettuat Sayımları ve Bu Sayımları Düzenleyen Nizamname Örnekleri”, OTAM, Say1:11, 2000, ss 669-823.

Algar, Hamid, "Molla", Türkiye Diyanet Vakfi İslam Ansiklopedisi, Cilt:10, Türkiye Diyanet Vakfi Yayınları, İstanbul 2005, s.238.

Arslan, İsmail, "XIX. Yüzyıl Osmanlı Tarihinde Temettuat Defterlerinin Yeri:Ĭğdiç Selimağa Köyü Temettuat Defteri Örneği”, Balıkesir Üniversitesi Sosyal Bilimler Enstitüsü Dergisi, Balıkesir 2002, ss.58-86.

Arslan, İsmail, Osmanlı Dünyasında Köyler ve Köylüler, Bilge Kültür Sanat, İstanbul 2014.

Aslan, Sevcan, Temettuât Defterlerine Göre XIX. YY. Ortalarında Gümüşhacıköy Kazası'nın Sosyo-Ekonomik Durumu (1844-1845),Yayımlanmamış Yüksek Lisans Tezi, Eskişehir Osmangazi Üniversitesi Sosyal Bilimler Enstitüsü, Eskişehir 2015. 
Bozkurt Nebi - İpşirli Mehmet, "Lakap”, Türkiye Diyanet Vakfi İslam Ansiklopedisi, Cilt: 27, Türkiye Diyanet Vakfi Yayınları, Ankara 2003, ss.65-67.

Canatar, Mehmet, "Kethüda", Diyanet Vakfi Íslam Ansiklopedisi, Cilt: 25, Türkiye Diyanet Vakfi Yayınları, 1991, s.332.

Çağlar, Ilker Mümin,“Temettuat Kayıtlarına Göre İzzeddin Köyü’nün Sosyo Ekonomik Durumu (1844-1845)”, Sosyal Bilimler Dergisi, 2015, s.414-444.

Çakır, Coşkun, Tanzimat Dönemi Osmanlı Maliyesi, Küre Yayınları, İstanbul 2001.

Çavdar, Necati, “1844-1845 yıllarında Taşabad Kazası Köylerinin İçtimai ve İktisadi Şartlarına Dair Tespitler” III. Uluslararası Geçmişten Günümüze Merzifon ve Amasya Yöresi Seтроzуuти Bildiri Kitabı, 2015, s.208-232.

Çimen, Adnan, "Sayım Kayıt Düzeni ve Teşkilatlanma Açısından Osmanlı Nüfus Hizmetleri”, Gazi Üniveristesi İktisadi ve idari Bilimler Fakültesi Dergisi, 2012, ss.183-216

Elibol, Numan, “Osmanlı İmparatorluğu'nda Nüfus Meselesi ve Demoğrafi Araştırmaları", Süleyman Demirel Üniversitesilktisadi ve İdari Bilimler Fakültesi Dergisi, Sayı:12, 2007, s.135- 160 .

Göyünç, Nejat, "Hane Deyimi Hakkında”, Tarih Dergisi, 1979, s.331-348.

Güneş, Mehmet, “Osmanlı Dönemi Nüfus Sayımları ve Bu Sayımları İçeren Kayıtların Tahlili”, Akademik Bakış, 2014, ss.221-240.

Güran, Tevfik, 19. Yüzyıl Osmanlı Tarımı Üzerine Araştırmalar, Eren Yayıcılık, İstanbul, 1998, s. 80 .

İslamoğlu, Hurcihan, Osmanlı İmparatorluğu’nda Devlet ve Köylü, İletişim Yayınları, İstanbul 1991, s. 94.

Kahriman Salih - Gür Fevzi, Amasya Nüfus Defterleri 1840, Amasya Belediyesi yayınları, 2012.

Koç, Yunus, "Nüfus", Türkiye Diyanet Vakfi İslam Ansiklopedisi, Cilt:33, Türkiye Diyanet Vakf1 Yayınları, 2007, s.293.

Köprülü, Orhan Fuad, "Efendi”, Türkiye Diyanet Vakfi İslam Ansiklopedisi, Cilt:10, Türkiye Diyanet Vakfı Yayınları, İstanbul 2012, s.456.

Kurt, Songül Keçeci, “1844-1845 Temettuat Defterlerine Göre Ziyere Köyü’nün Sosyal ve Ekonomik Durumu', History Studies, C.8, S.3, 2016, ss.57-81.

Kütükoğlu, Mübahat, "Osmanlı Sosyal ve İktisadi Tarihi Kaynaklarından Temettü Defterleri”, Belleten, Say1:225, 1995, ss.395-412.

Öz, Mehmet, “Tahrir”, Türkiye Diyanet Vakfi İslam Ansiklopedisi, Cilt:39, Türkiye Diyanet Vakfi Yayınları, 2010, s.426.

Özaydın Abdülkerim - İpşirli Mehmet, "Unvan”, Türkiye Diyanet Vakfi İslam Ansiklopedisi, Cilt:30, Türkiye Diyanet Vakfı Yayınları, İstanbul 2012, s.163.

Özcan, Selim, "H.1256 (1840) Tarihli Amasya Nüfus Defterleri ile H.1260-1261(1844- 1845) Tarihli Amasya Temettuat Defterlerinin Karşılaştırmalı Değerlendirilmesi”, Studies of The Otoman Domain, C.6, S.11, 2016, s.97-118. 
Özel, Oktay, “Avarız ve Cizye Defterleri”, Editör: H. İnalcık ve Ş. Pamuk, Osmanlı Devleti’nde Bilgi ve İstatistik, Ankara 2000, s.35-50.

Özlü, Zeynel, Tanzimat Dönemi'nde Anadolu'da Kır ve Kent hayatı (Bolu- Göynük Örneği), Berikan Yayınları, Ankara 2007.

Öztürk, Said, “XIX. Yüzyılda Söğüd'ün Sosyo-Ekonomik Yapısı”, Türk Dünyası Tarih Dergisi, İstanbul Kitabevi, 1996.

Öztürk, Said, Tanzimat Döneminde Bir Anadolu Şehri Bilecik, Kitapevi, İstanbul, s. 19.

Serbestoğlu, İbrahim, 19.Yüzyılda Amasya Sancă̆ı, Amasya 2018, s.28.

Soydal, Tayfun, Temettuat Defterlerine Göre Ezinepazar Nahiyesinin Sosyal ve Ekonomik Durumu, Yayımlanmamış Yüksek Lisans Tezi, Amasya Üniversitesi Sosyal Bilimler Enstitüsü, Amasya 2018, s.28.

Yaşar, Hüseyin Hüsameddin, Amasya Tarihi, Hazırlayan M.Aydın ve G.Aydın, Amasya Belediyesi, Amasya 2007, s.231.

Yıldırım, Rıza, Temettuat Defterlerine Göre Geldiklan Nahiyesi'nin Sosyal ve Ekonomik Durumu, Yayımlanmamış Yüksek Lisans Tezi, Amasya Üniversitesi Üniversitesi Sosyal Bilimler Enstitüsü, Amasya 2017, s.42. 